\title{
SPATIAL PATTERNS OF DOMESTIC AIR PASSENGER TRAFFIC GENERATION IN NIGERIA
}

Emmanuel Chukwuka Bardi

Emesoch Logistics and Consultancy Services, Lagos, Nigeria

\begin{abstract}
This study aims at analyzing the spatial patterns of domestic air passenger traffic generated by the interacting city-pairs in Nigeria's air transportation system at five points in time - 2003, 2006, 2010, 2014 and 2018 to establish the spatial and temporal changes that have taken place over time. It also examined the relationships between the populations of the cities and the volumes of domestic air passenger traffic generated by the cities to establish the impact of population on the traffic generating capacity of the cities. The volumes of domestic air passengers handled by each city, the percentage share of total traffic, the populations of the cities, the Pearson's Product Moment Correlation Coefficient and the student's ' $t$ ' test were used for the analyses. The study revealed that Lagos was the dominant domestic air passenger traffic generation centre. It established that few centres generated most of the domestic air passenger traffic in Nigeria and that the spatial pattern of traffic generation tended more towards concentration than dispersal. The study also found that there were statistically positive relationships between the populations of the cities and the volumes of traffic generated by the cities. Balanced regional development is recommended, among others, to help redistribute population among the cities in the air transportation system in Nigeria so as to increase their air passenger traffic generating capacity.
\end{abstract}

\section{KEYWORDS}

Domestic air passenger traffic, Traffic Generation, Concentration, Population, Generating Capacity, Balanced Regional development 


\section{INTRODUCTION}

Transportation involves the movement of people, goods, services and information between points in space. It helps in creating useful links between regions and economic activities; between people and the rest of the world (Rodigue et al, 2006). Air transportation is the use of aircraft in moving people, goods and information from one point to another. The development of air transportation in Nigeria started after the World War 11 and it has since then, like other transportation modes, contributed to the socio - economic development of Nigeria, especially in areas of movement of people and goods within the country and across international borders, generation of revenue and employment.

Air traffic is classified into passenger, freight and mail. In Nigeria, domestic air traffic is classified into passenger, cargo, mail and excess luggage. Cargo and excess luggage constitute freight traffic (Filani, 1975). Domestic air passenger traffic is the air passenger traffic exchanged by the city-pairs within the air transportation system in any country, including Nigeria. Domestic air passenger traffic pre-dominated the air transport system in Nigeria. It accounted for $71.73 \%$ in $2003,72.80 \%$ in $2004,72.13 \%$ in 2014 and $74.24 \%$ in 2018 (NCAA, 2003, 2004, 2014 and NBS, 2018). The number of domestic air passengers lifted in Nigeria increased to over 8,000,000 in 2007 (Abioye, 2009), over 11,700,000 in 2014 (NCAA, 2014) and over 12,000,000 in 2018 (NBS, 2018).

Nigeria is a relatively large country where population and economic activities are concentrated in certain points, both far from and near to each other. This spatial arrangement generates spatial interaction between various points of concentration of population, economic, sociocultural and political activities within the country.

Early research works on spatial interaction have identified population as a primary factor that determined airline passenger traffic patterns. Harvey (1951) examined the factors determining the airline passenger traffic pattern within the United States and identified population of the communities in a pair as well as the distances between them as the primary factors affecting traffic flow. In a similar study, Taaffe (1956) has shown that urban population is a dominant factor affecting concentration of air passenger traffic in the United States.

More recent studies on traffic interaction have incorporated additional factors - attractive forces such as Gross Domestic Product (GDP), employment, per capita income, percentage of employees and frictional forces including travel time, travel cost and scheduled frequency. The outcome of the studies still identified population as a prominent factor affecting concentration of air passenger traffic. Alam and Karim (1997) developed city-pair demand 
models for the analysis of domestic air transportation in Bangladesh using demand and supply variables of population, employment, Gross Domestic Product (GDP), dummy, travel time, travel cost and distance. The study indicated that population was a dominant and highly significant variable affecting domestic air traffic, followed by GDP and employment. This result was supported by the findings of the research by Masumoto (2005) on the hubness of Asian major cities in terms of air traffic patterns. The result of his study indicated that population was more important in explaining air traffic flows than GDP. Sivrikaya and Tunç (2013) also indicated that urban population, distance, and number of beds in tourism facility were found to have significantly boosted domestic air transport demand by city-pair level in Turkey. Cohen (2016), in his explanation of global city-pair air travel demand and forecasting of air traffic flows found, among other things, that population and income (measured as GDP) were very important drivers of travel demand. Bardi (2017) also examined the effect of population variable on domestic air passenger traffic flow in Nigeria and established that population had significant positive influence on domestic air passenger traffic flow in Nigeria during the 2003, 2006, 2010 and 2014 periods.

A lot of changes have taken place over the years in the domestic air transport arena in Nigeria. The Nigerian government has formally liberalized the air transport sector since 2001 and as at 2018, many private airlines, among which were Aero Contractors, Arik Airlines, First Nation Airlines, Dana Airlines, Peace Airlines, Medview Airlines, Overland Airways, Azman Airlines and Max Airlines participated in the provision of domestic air passenger services to take care of the increasing air passenger traffic. The situation has, therefore, changed and the new characteristics and pattern of generation of domestic air passenger traffic need to be established to ascertain the spatial and temporal changes that have taken place over time. This study was, therefore, conceived to analyze the spatial pattern of domestic air passenger traffic generation in Nigeria and since population had been identified as a prominent factor affecting air passenger traffic pattern it would, in addition, establish the relationship between the populations of the interacting city-pairs in Nigeria and the domestic air passenger traffic generated by the cities to ascertain the impact of population on the generating capacity of the cities.

\section{THE STUDY AREA}

This study focused mainly on Nigeria, which lies between Longitudes $3^{0}$ and $15^{0}$ east of the Greenwich Meridian and between Latitudes $4^{0}$ and $14^{\circ}$ north of the Equator. It covers an area of $923,769 \mathrm{~km}^{2}$. Nigeria is a relatively very populous country. The official census of 1963 put the population figure at 55,600,000 while that of 1991 was put at $88,500,000$. The results of the 2006 census put the total population of Nigeria at over $140,000,000$ and the density of 
the population was 139 persons/km² ((NPC 2007). In 2014 the population of Nigeria was estimated to be $177,500,000$ and according to World Population Review, (2019), Nigeria's population is estimated at 200,963,599 in July 2019, with estimated density of 212.04 persons $/ \mathrm{km}^{2}$ and growth rate of $2.62 \%$.

The level of urbanization i.e. the proportion of the population living in the urban centres in Nigeria in 2006 was $45 \%$ and the results of the 2006 census estimated the rate of urbanization in Nigeria to be 5.3\% /year (Federal Republic of Nigeria, 2008). The Federal Capital Territory, Abuja and all the state capitals are urban centres and all the Local Government Area Headquarters were given urban status during the 1976 Local Government Reforms and this increased the number of urban centres within the country. This increase in urbanization intensified the drift of population from the surrounding rural areas to the urban centres in order to explore the opportunities in them, thereby leading to concentration of population at specific points in the country. This concentration of population at specific points, the distances separating them and the various socio-economic activities going on in them increased the demand for transportation for effective interaction.

The expanding transportation systems in Nigeria provide the infrastructural basis that facilitates socio-economic development. The earliest form of transport in Nigeria is water transport and the other modes of transport are road, rail, pipeline, air and rope/cableways. Water transport dominated the transport system until 1912 when the first railway from Lagos to Kano was completed. Road transport was developed when motor vehicle was introduced in 1920 s and in the 1940 s air transport was developed.

The history of air transport dates back to the end of the World War 11 in 1945, and since its inception there has been a tremendous increase in the volume of air traffic. Over 450 scheduled flights were handled every day through domestic and international flights in 2007 (Abioye, 2008) and the number increased to 724 in 2008 (Abioye, 2009). In 2014 the total scheduled domestic aircraft movement in Nigeria was 137,927 (NCAA, 2014) and the number increased to 234,367 in 2018 (NBS, 2018).The Federal Government of Nigeria has been spending huge capital on the aviation sector. In 2004 Appropriation Act a total of $\mathrm{A} 4,620,700,000$ was allocated to the aviation sector and this jumped to $\mathrm{A} 21,711,466,589$ in 2007 and further increased to $\mathrm{N} 36,579,702,475$ in 2008 Appropriation Act (Federal Republic of Nigeria, 2004, 2007 and 2008). However, the total allocation to the aviation sector decreased to $\mathrm{A} 34,829,565,713$ in the 2011 budget and to $\mathrm{A} 32,308,750,792$ in the 2014 budget (Federal Republic of Nigeria, 2011 and 2014). 
As at 1986 there were 16 government-owned airports controlled by the Nigeria Airports Authority. The number increased to 25 in 2014 as can be seen in Figure 1. In addition, there were many public and private landing strips located at places approved by the government.

Figure 1. Airports in Nigeria

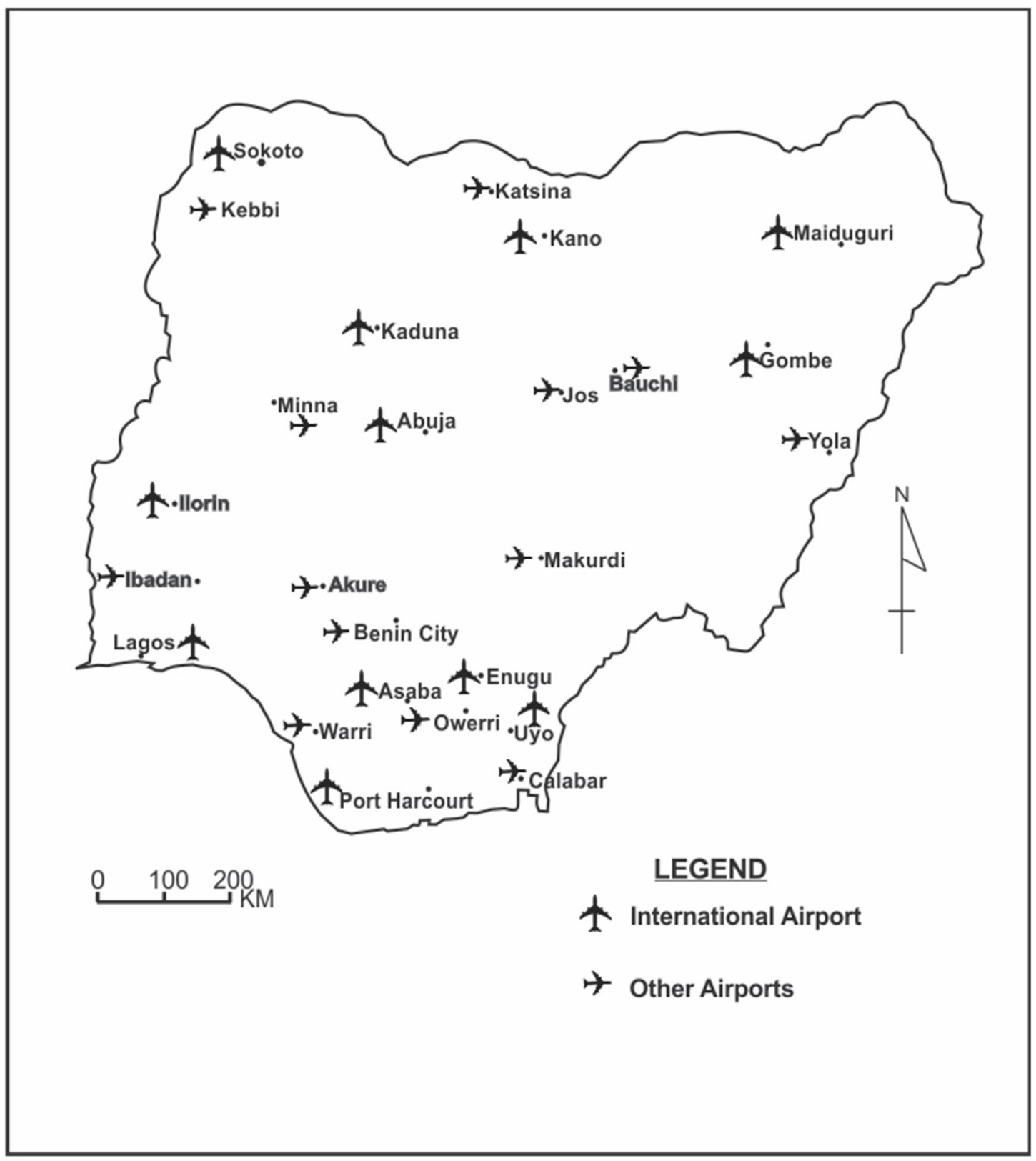

Source: Produced from the Data obtained from the NCAA

\section{DATA AND METHODS}

This study was based on domestic air passenger traffic data from all airlines that provided scheduled domestic air passenger services in Nigeria at five points in time - 2003, 2006, 2010, 2014 and 2018; the volumes of traffic generated by each city in the domestic air network; 
their percentage share of total domestic air passenger traffic, and the population of each city. All the cities in the domestic air network and the volume of domestic air passenger traffic generated by each city, which included the outgoing (departure) and incoming (arrival) traffic, were obtained from the Nigerian Civil Aviation Authority (NCAA). The population figures for the cities were obtained from the Nigerian Population Commission (NPC). The volumes of traffic generated by each city and their percentage share of total traffic from all airports, as given by the NCAA, were used for the analyses.

The 1991 population census figures were used for the projection of the population of cities within the air transport system during the study periods. The 1991 census population figures for the cities were projected to the figures for 2003, 2006, 2010, 2014 and 2018, using the growth rates of $9.3 \%$ for Abuja, $4.7 \%$ for Lagos and $3.2 \%$ for other cities, and the formula $P_{1}=P_{0} e^{r . t}$

Where $P_{1}$ is the projected population, $P_{0}$ is the base population; $r$ is the rate of population growth; $\mathrm{t}$ is the time interval; $\mathrm{e}$ is the exponential of the product of $\mathrm{r}$ and $\mathrm{t}$.

It would have been ideal to use the 2006 population census figures (the most recent then) for the projection but the 2006 figures were rendered in national, state and local government levels and did not record the population of the individual cities. The 1991 population census figures recorded the population of the individual cities hence the 1991 figures were used for the projection. The relationship between the populations of the cities and the volumes of traffic generated by each city was established, using the Pearson's Product Moment Correlation Coefficient and the significance of the relationship was tested using the Student's 't' test.

\section{RESULTS AND DISCUSSION}

\subsection{Spatial patterns of Domestic Air Passenger Traffic Concentration}

The volume of domestic air passenger traffic handled by each city within Nigeria's domestic air transportation system during the five time periods - 2003, 2006, 2010, 2014 and 2018 and their percentage share of total domestic air passenger traffic are shown in Tables 1, 2, 3, 4 and 5. Table 1 shows that in 2003, Lagos played a dominant role in traffic generation. It accounted for $39.09 \%$ of Nigeria's total domestic air passenger traffic. Other centres that generated heavy traffic in 2003 were Abuja (23.98\%), Port Harcourt (14. 44\%), Warri (6.64\%), Enugu (3.45\%) and Kano (2.83\%). These six centres - Lagos, Abuja, Port Harcourt, Warri, Enugu and Kano generated $90.43 \%$ of the total domestic air passenger traffic in 2003. 
The pattern of distribution of the total domestic air passengers handled at each airport in 2003 is illustrated in Figure 2.

Table 1. Total Domestic Air Passengers Handled by the Nigerian Airports in 2003 and their Percentage share of traffic

\begin{tabular}{|c|c|c|c|c|c|}
\hline S/NO. & \multicolumn{2}{|c|}{ PASSENGER } & MOVEMENT & TOTAL & $\begin{array}{c}\text { PERCENTAGE SHARE OF } \\
\text { TRAFFIC }\end{array}$ \\
\cline { 1 - 2 } & AIRPORT & ARRIVAL & DEPARTURE & & 23.98 \\
\hline 1. & ABUJA & 709,251 & 706,755 & $1,416,006$ & 0.05 \\
\hline 2. & AKURE & 1,615 & 1,422 & 3,037 & 0.03 \\
\hline 3. & BAUCHI & 895 & 864 & 1,759 & 1.20 \\
\hline 4. & BENIN & 35,695 & 35,038 & 70,733 & 2.07 \\
\hline 5. & CALABAR & 60,577 & 61,362 & 121,939 & 3.45 \\
\hline 6. & ENUGU & 99,216 & 104,800 & 204,016 & 0.09 \\
\hline 7. & IBADAN & 2,574 & 2,486 & 5,060 & 0.10 \\
\hline 8. & ILORIN & 3,022 & 2866 & 5,888 & 0.75 \\
\hline 9. & JOS & 23,142 & 20,937 & 44,079 & 2.09 \\
\hline 10. & KADUNA & 62,979 & 60,435 & 123,414 & 2.83 \\
\hline 11. & KANO & 84,646 & 82,414 & 167,069 & 0.03 \\
\hline 12. & KATSINA & 869 & 888 & 1,757 & 39.09 \\
\hline 13. & LAGOS & $1,150,013$ & $1,158,757$ & $2,308,770$ & 1.18 \\
\hline 14. & MADUGURI & 35,094 & 34,399 & 69,493 & 0.04 \\
\hline 15. & MAKURDI & 984 & 1525 & 2509 & 0.08 \\
\hline 16. & MINNA & 2,329 & 2,492 & 4,821 & 0.76 \\
\hline 17. & OWERRI & 25,011 & 20,093 & 45,104 & 14.44 \\
\hline 18. & PORT HARCOURT & 451,638 & 400,883 & 852,521 & 0.37 \\
\hline 19. & SOKOTO & 10,234 & 11,550 & 21,784 & 6.64 \\
\hline 20. & WARRI & 197,639 & 194,276 & 391,915 & 0.77 \\
\hline 21. & YOLA & 22,602 & 23,313 & 45,915 & $\mathbf{1 0 0}$ \\
\hline & TOTAL & $\mathbf{2 , 9 7 9 , 0 4 1}$ & $\mathbf{2 , 9 2 6 , 0 3 0}$ & $\mathbf{5 , 9 0 5 , 0 7 1}$ & \\
\hline & & & & \\
\hline
\end{tabular}

Source: Nigerian Civil Aviation Authority (NCAA) Statistical Data, 2003 
Figure 2. Per Cent Distribution of Domestic Air Passenger Traffic Handled By Each City, 2003.

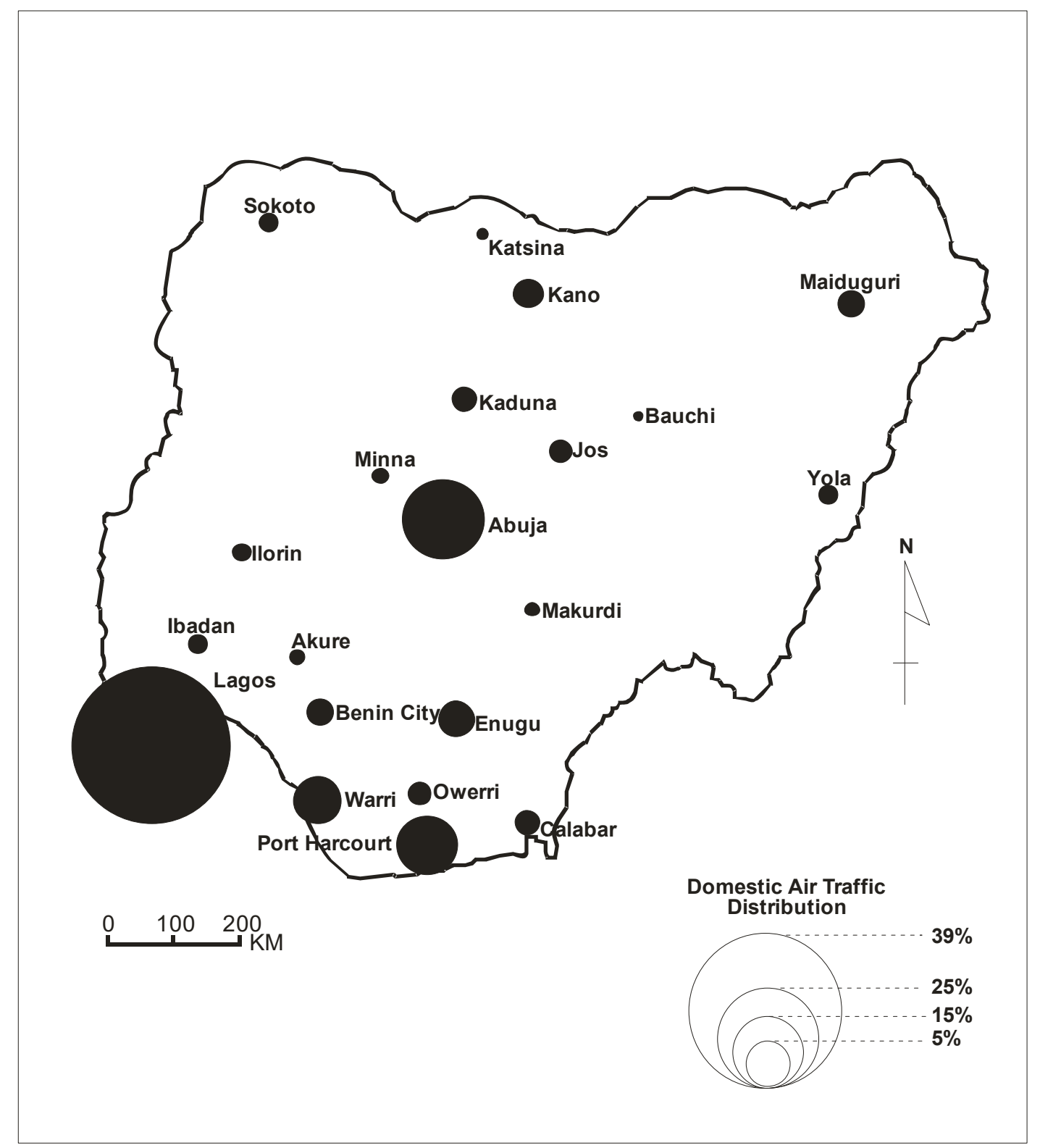

Source: Produced from NCAA Statistical Data for 2003

Table 2 shows that in 2006, Lagos dominated the generation of domestic air passenger traffic as it accounted for $43.75 \%$ of the total domestic air passenger traffic generated in Nigeria. The six - heavy traffic generating centres - Lagos (43.75\%), Abuja (24.68\%), Port Harcourt $(8.81 \%)$, Owerri $(4.85 \%)$, Warri (3.82\%) and Enugu (2.94\%) generated $80.1 \%$ of the total domestic air passenger traffic in Nigeria. The pattern of traffic generation in 2006 is shown in Figure 3. 
Table 2. Total Domestic Air Passengers Handled by the Nigerian Airports in 2006 and their percentage share of traffic

\begin{tabular}{|c|c|c|c|c|c|}
\hline S/NO. & \multicolumn{2}{|c|}{ PASSENGER } & MOVEMENT & TOTAL & $\begin{array}{c}\text { PERCENTAGE SHARE } \\
\text { OF TRAFFIC }\end{array}$ \\
\hline 1. & AIRPORT & ARRIVAL & DEPARTURE & & 24.68 \\
\hline 2. & ABUJA & 802,571 & 804,850 & $1,607,421$ & 0.05 \\
\hline 3. & AKURE & 1,548 & 1,488 & 3,036 & 0.02 \\
\hline 4. & BAUCHI & 527 & 625 & 1,152 & 1.40 \\
\hline 5. & BENIN & 45,532 & 45,924 & 91,456 & 2.56 \\
\hline 6. & EALABAR & 83,123 & 83,631 & 166,754 & 2.94 \\
\hline 7. & IBADAN & 5,646 & 6,596 & 12,242 & 0.19 \\
\hline 8. & ILORIN & 10,159 & 9,064 & 19,223 & 0.30 \\
\hline 9. & JOS & 16,304 & 14,454 & 30,758 & 0.47 \\
\hline 10. & KADUNA & 54,749 & 54,412 & 109,161 & 1.68 \\
\hline 11. & KANO & 80,361 & 74,306 & 154,657 & 2.37 \\
\hline 12. & KATSINA & 216 & 189 & 405 & 0.01 \\
\hline 13. & LAGOS & $1,415,605$ & $1,434,155$ & $2,849,760$ & 43.75 \\
\hline 14. & MADUGURI & 14,965 & 15,717 & 30,682 & 0.47 \\
\hline 15. & MAKURDI & 120 & 122 & 242 & 0.004 \\
\hline 16. & MINNA & 4,277 & 3,219 & 7,496 & 0.12 \\
\hline 17. & OWERRI & 168,568 & 147,031 & 315,599 & 4.85 \\
\hline 18. & PORT HARCOURT & 278,110 & 295,697 & 573,807 & 8.81 \\
\hline 19. & SOKOTO & 17,820 & 28,109 & 45,929 & 0.71 \\
\hline 20. & WARRI & 128,456 & 120,281 & 248,737 & 3.82 \\
\hline 21. & YOLA & 26,453 & 27,094 & 53,547 & 0.82 \\
\hline & TOTAL & $\mathbf{3 , 2 5 2 , 9 8 3}$ & $\mathbf{3 , 2 6 0 , 5 2 2}$ & $\mathbf{6 , 5 1 3 , 5 0 5}$ & $\mathbf{1 0 0}$ \\
\hline & & & & 191,441 & \\
\hline
\end{tabular}

Source: NCAA Statistical Data, 2006 
Figure 3. Per Cent Distribution of Domestic Air Passenger Traffic Handled By Each City, 2006.

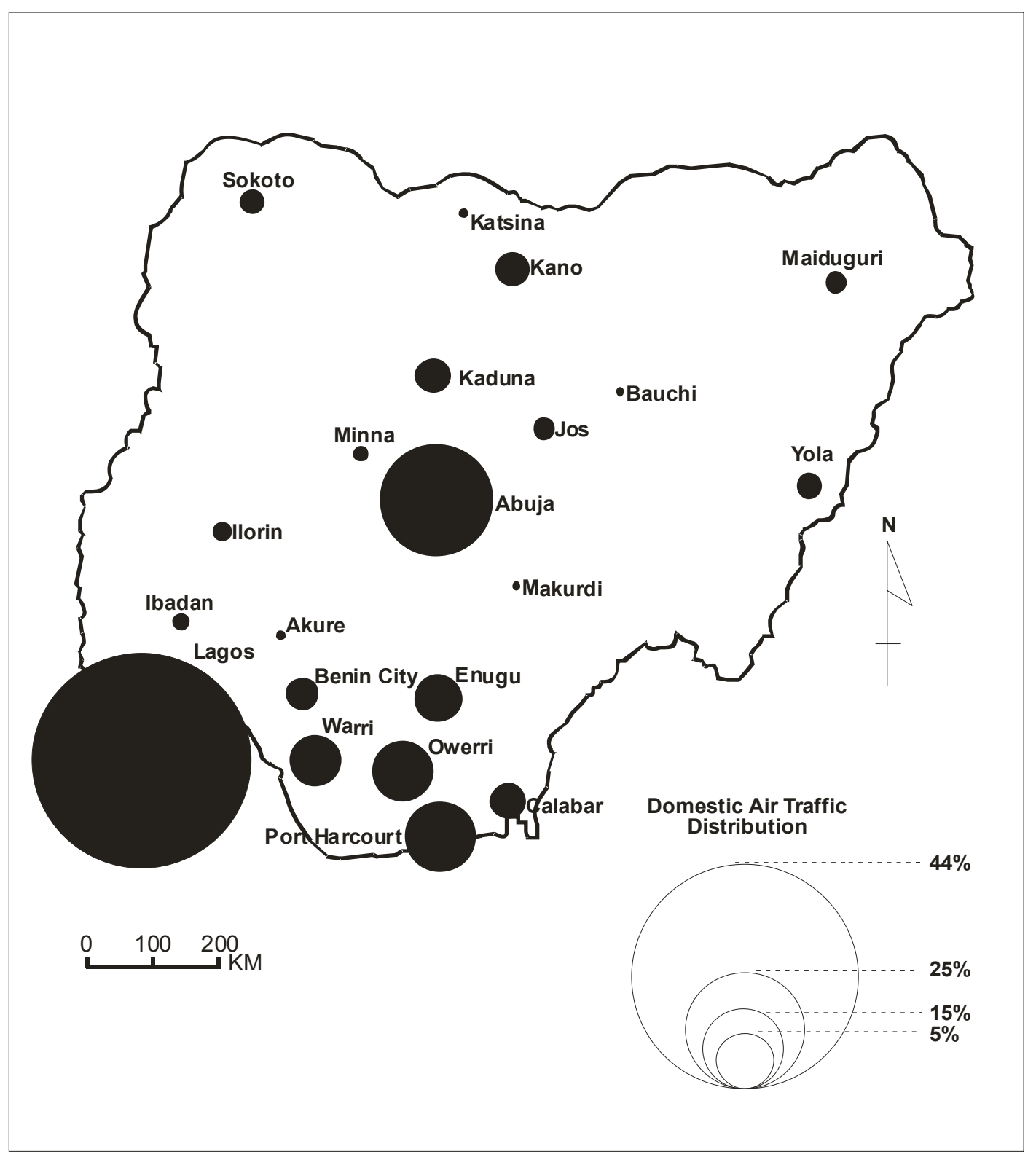

Source: Produced from NCAA Statistical Data for 2006

In 2010, Lagos dominated the air passenger traffic generation in Nigeria. As can be seen from Table 3, Lagos accounted for $40.60 \%$ of the total domestic air passengers. As in other years, there were six heavy traffic generating centres in 2010, namely Lagos (40.60\%), Abuja (30.88\%), Port Harcourt (8.73\%), Owerri (3.91\%), Benin $(2.90 \%)$, and Calabar $(2.36 \%)$. These six centres generated $89.3 \%$ of the total domestic air passenger traffic generated in 2010. This pattern of traffic generation is illustrated in Figure 4. 
Table 3. Total Domestic Air Passengers Handled by the Nigerian Airports in 2010 and their Percentage Share of Traffic

\begin{tabular}{|c|c|c|c|}
\hline S/NO. & AIRPORT & $\begin{array}{c}\text { TOTAL } \\
\text { PASSENGER }\end{array}$ & PERCENTAGE SHARE OF TRAFFIC \\
\hline 1. & ABUJA & $1,643,838$ & 30.88 \\
\hline 2. & AKURE & 2,766 & 0.52 \\
\hline 3. & BAUCHI & 00000 & 0.00 \\
\hline 4. & BENIN & 154,558 & 2.90 \\
\hline 5. & CALABAR & 125,418 & 2.36 \\
\hline 6. & ENUGU & 11,875 & 0.22 \\
\hline 7. & IBADAN & 17,976 & 0.34 \\
\hline 8. & ILORIN & 23,714 & 0.45 \\
\hline 9. & JOS & 37,064 & 0.70 \\
\hline 10. & KADUNA & 83,931 & 1.58 \\
\hline 11. & KANO & 124,963 & 2.35 \\
\hline 12. & KATSINA & 5,262 & 0.10 \\
\hline 13. & LAGOS & $2,161,264$ & 40.60 \\
\hline 14. & MADUGURI & 47,301 & 0.89 \\
\hline 15. & MAKURDI & 0000 & 0.00 \\
\hline 16. & MINNA & 950 & 0.02 \\
\hline 17. & OWERRI & 208,267 & 3.91 \\
\hline 18. & PORT HARCOURT & 464,945 & 8.73 \\
\hline 19. & SOKOTO & 29,188 & 0.55 \\
\hline 20. & WARRI & 69,894 & 1.31 \\
\hline 21. & YOLA & 51,440 & 0.97 \\
\hline 22. & GOMBE & 5,224 & 0.10 \\
\hline 23. & UYO & 53,199 & 1.00 \\
\hline \multicolumn{2}{|r|}{ TOTAL } & $5,323,035$ & 100 \\
\hline
\end{tabular}

Source: Computed from the NCAA Statistical Data, 2010 
Figure 4. Per Cent Distribution of Domestic Air Passenger Traffic Handled by Each City, 2010.

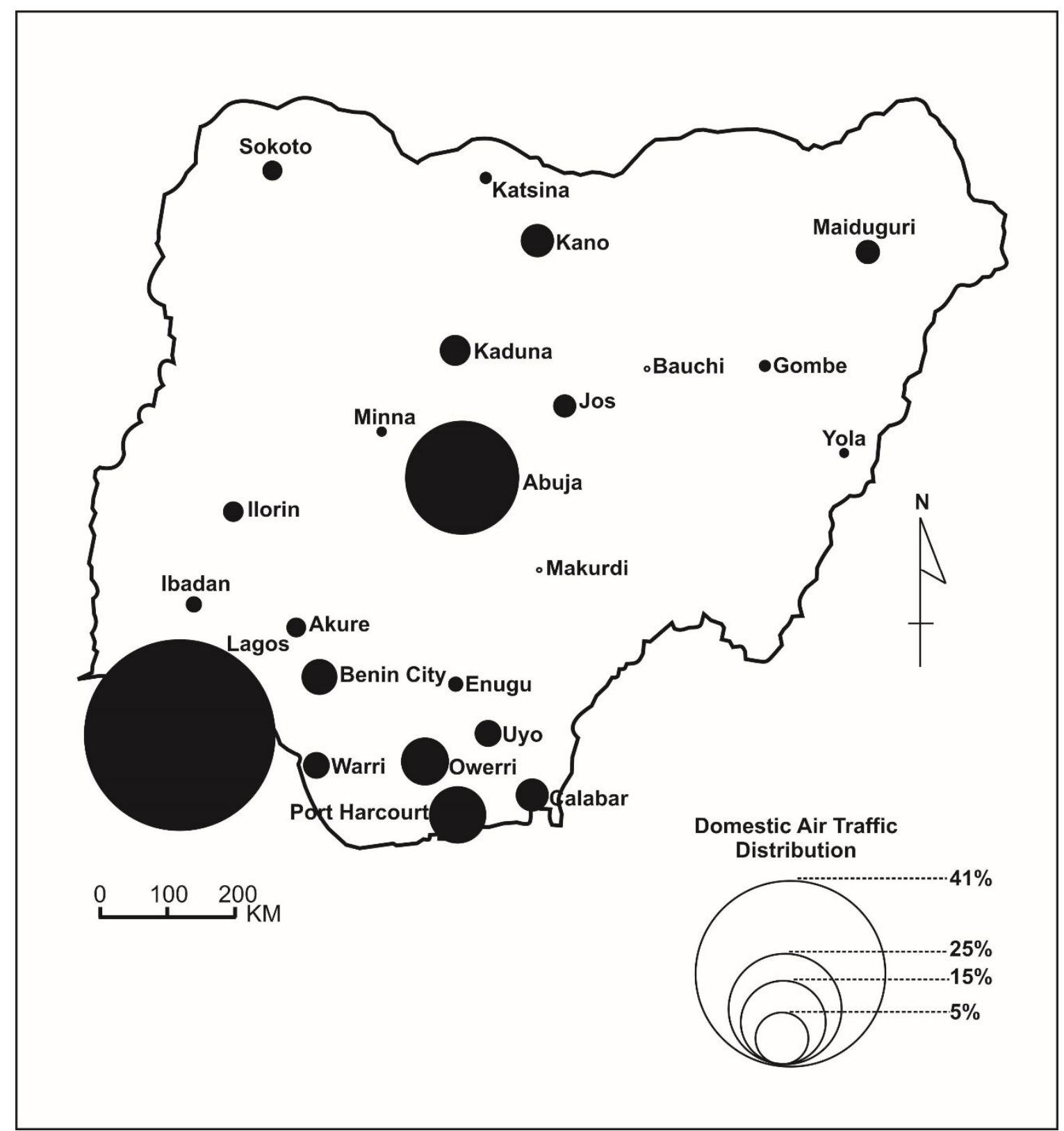

Source: Produced from NCAA Statistical Data for 2010

In 2014, Lagos continued to dominate the domestic air passenger traffic generation in Nigeria. It generated $37.13 \%$ of the total traffic. Lagos and the other five heavy traffic generating centres generated $84.08 \%$ of the total domestic air passenger traffic, viz - Lagos $(37.13 \%)$, Abuja (28.75\%), Port Harcourt (10.46\%), Owerri (2.74\%), Uyo (2.5\%) and Kano (2.5\%). The pattern of distribution of the traffic in 2014 is shown in Table 4 and Figure 5. 
Table 4. Total Domestic Air Passengers Handled by the Nigerian Airports in 2014 and their percentage share of Traffic

\begin{tabular}{|c|c|c|c|c|c|}
\hline \multirow[t]{2}{*}{ S/NO. } & \multicolumn{2}{|c|}{ PASSENGER } & \multirow{2}{*}{$\begin{array}{l}\text { MOVEMENT } \\
\text { DEPARTURE }\end{array}$} & \multirow[t]{2}{*}{ TOTAL } & \multirow{2}{*}{$\begin{array}{c}\text { PERCENTAGE SHARE } \\
\text { OF TRAFFIC }\end{array}$} \\
\hline & AIRPORT & ARRIVAL & & & \\
\hline 1. & ABUJA & $1,687,312$ & $1,680,657$ & $3,367,969$ & 28.75 \\
\hline 2. & AKURE & 3,675 & 3,245 & 6,920 & 0.06 \\
\hline 3. & ASABA & 86,993 & 83,854 & 170,847 & 1.46 \\
\hline 4. & BAUCHI & 7,786 & 9,202 & 16,988 & 0.15 \\
\hline 5. & BENIN & 123,691 & 110,494 & 234,185 & 2.0 \\
\hline 6. & CALABAR & 99,765 & 101,456 & 201,221 & 1.72 \\
\hline 7 & ENUGU & 146,462 & 141,059 & 287,521 & 2.45 \\
\hline 8 & GOMBE & 15,883 & 15,487 & 31,370 & 0.26 \\
\hline 9. & IBADAN & 38,390 & 37,074 & 75,464 & 0.64 \\
\hline 10. & ILORIN & 43,137 & 42,853 & 85,990 & 0.73 \\
\hline 11. & JOS & 34,480 & 31,955 & 66,435 & 0.57 \\
\hline 12. & KADUNA & 94,212 & 95,215 & 192,427 & 1.64 \\
\hline 13. & KANO & 153,910 & 138,391 & 292,301 & 2.5 \\
\hline 14. & KEBBI & 984 & 1,081 & 2,065 & 0.02 \\
\hline 15. & LAGOS & $2,170,084$ & $2,179,287$ & $4,349,371$ & 37.13 \\
\hline 16. & MAIDUGURI & 10,695 & 9,071 & 19,766 & 0.17 \\
\hline 17. & MINNA & 3,475 & 0 & 3,475 & 0.03 \\
\hline 18. & OWERRI & 161,602 & 159,079 & 320,681 & 2.74 \\
\hline 19. & PORT HARCOURT & 613,382 & 611,640 & $1,225,022$ & 10.46 \\
\hline 20. & SOKOTO & 49,021 & 50,624 & 99,645 & 0.85 \\
\hline 21. & UYO & 144,629 & 147,732 & 292,361 & 2.5 \\
\hline 22. & WARRI & 108,257 & 109,110 & 217,367 & 1.86 \\
\hline 23. & YOLA & 76,336 & 76,211 & 154,547 & 1.32 \\
\hline & TOTAL & $5,879,161$ & $5,834,777$ & $11,713,938$ & 100 \\
\hline
\end{tabular}

Source: Computed from the NCAA Statistical Data, 2014. 
Figure 5. Per Cent Distribution of Domestic Air Passenger Traffic Handled by Each City, 2014.

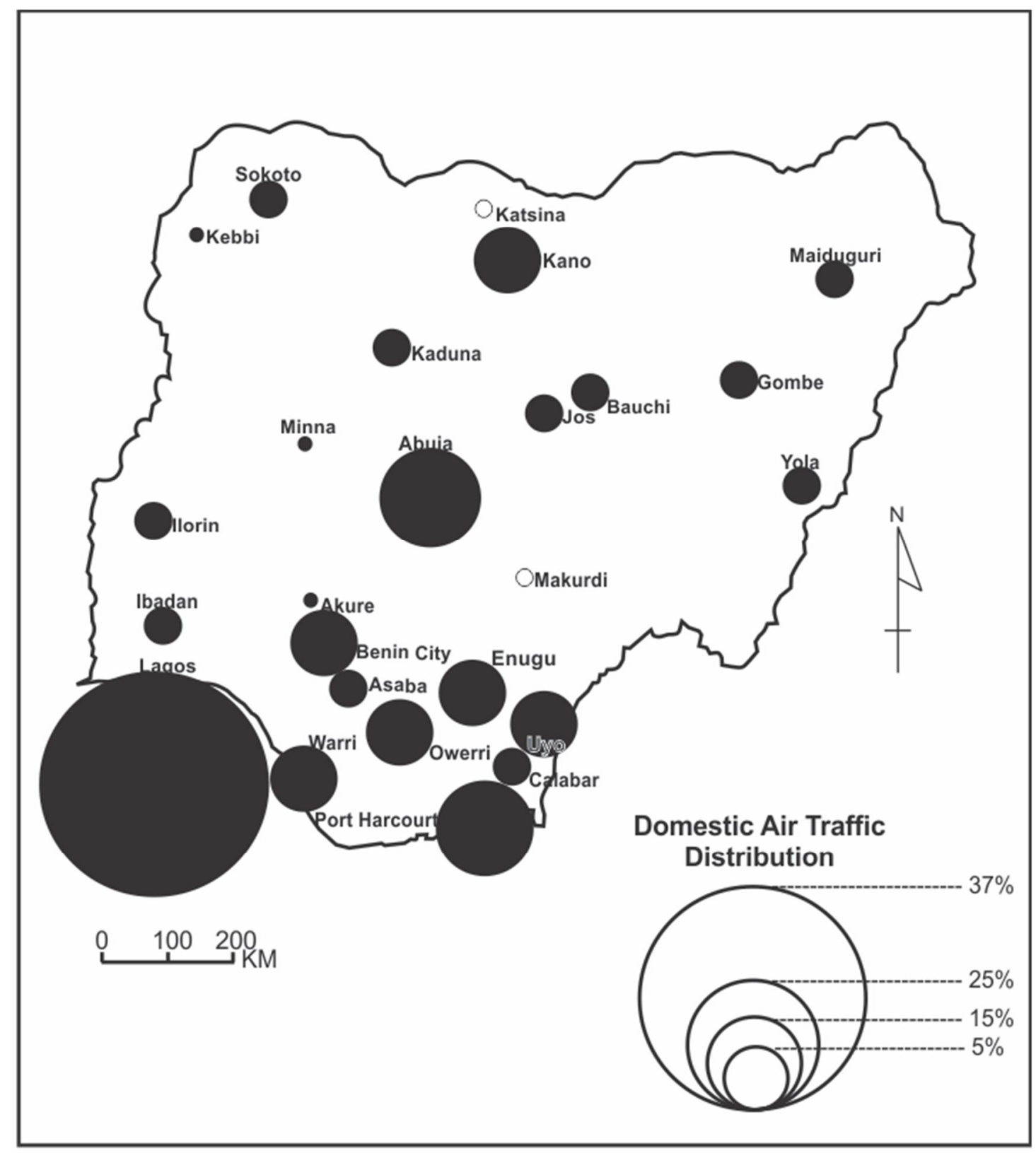

Source: Produced from NCAA Statistical Data for 2014.

In 2018, Lagos still dominated the domestic air passenger traffic generation in Nigeria. It generated $33.88 \%$ of the total domestic air passengers. As shown in Table 5 there were sixheavy traffic generating centres in 2018. The six centres and the percentage of total domestic air passengers generated were Lagos (33.88\%), Abuja (30.83\%), Port Harcourt $(8.56 \%)$, Owerri (4.07\%), Kano (3.25\%) and Enugu (2.72\%). These six centres generated $83.31 \%$ of the total domestic air passenger traffic in 2018. The pattern of Domestic air passenger traffic generation in 2018 is illustrated in Table 5 and Figure 6. 
Table 5. Total Domestic Air Passengers Handled by the Nigerian Airports in 2018 and their percentage share of Traffic

\begin{tabular}{|c|c|c|c|c|c|}
\hline \multirow[t]{2}{*}{ S/NO } & \multicolumn{2}{|c|}{ PASSENGER } & \multirow{2}{*}{$\begin{array}{l}\text { MOVEMENT } \\
\text { DEPARTURE }\end{array}$} & \multirow[t]{2}{*}{ TOTAL } & \multirow{2}{*}{$\begin{array}{c}\text { PERCENTAGE SHARE } \\
\text { OF TRAFFIC }\end{array}$} \\
\hline & AIRPORT & ARRIVAL & & & \\
\hline 1. & ABUJA & $1,931,295$ & $1,931,788$ & $3,863,083$ & 30.83 \\
\hline 2. & AKURE & 30,656 & 31,730 & 62,386 & 0.50 \\
\hline 3. & ASABA & 33,201 & 32,663 & 65,864 & 0.53 \\
\hline 4. & BAUCHI & 18,191 & 17,949 & 36,140 & 0.29 \\
\hline 5. & BENIN & 154,277 & 160,922 & 320,199 & 2.56 \\
\hline 6. & CALABAR & 81,912 & 84,240 & 166,152 & 1.33 \\
\hline 7 & ENUGU & 170,448 & 170,591 & 341,039 & 2.72 \\
\hline 8 & GOMBE & 28,392 & 28,011 & 56,403 & 0.45 \\
\hline 9. & IBADAN & 46,265 & 45,835 & 92,100 & 0.74 \\
\hline 10. & ILORIN & 57,276 & 56,691 & 113,967 & 0.91 \\
\hline 11. & JOS & 38,710 & 38,240 & 76,950 & 0.61 \\
\hline 12. & KADUNA & 83,667 & 85,281 & 168,948 & 1.35 \\
\hline 13. & KANO & 205,777 & 201,615 & 407,392 & 3.25 \\
\hline 14. & KEBBI & 14,928 & 15,257 & 30,185 & 0.24 \\
\hline 15. & LAGOS & $2,138,146$ & $2,107,001$ & $4,245,147$ & 33.88 \\
\hline 16. & MAIDUGURI & 100,702 & 101,238 & 201,940 & 1.61 \\
\hline 17. & MINNA & 1,336 & 1,362 & 2,698 & 0.02 \\
\hline 18. & OWERRI & 257,880 & 252,666 & 510,546 & 4.07 \\
\hline 19. & PORT HARCOURT & 538,068 & 534,910 & $1,072,978$ & 8.56 \\
\hline 20. & SOKOTO & 53,608 & 53,637 & 107,245 & 0.86 \\
\hline 21. & UYO & 116,169 & 116,658 & 232,827 & 1.86 \\
\hline 22. & WARRI & 87,478 & 87,594 & 175,072 & 1.40 \\
\hline 23. & YOLA & 89,587 & 92,423 & 182,010 & 1.45 \\
\hline & TOTAL & $6,282,969$ & $6,248,302$ & $12,531,271$ & 100.0 \\
\hline
\end{tabular}

Source: Computed from the NBS Air Transportation Data, 2018. 
Figure 6. Per Cent Distribution of Domestic Air Passenger Traffic Handled By Each City, 2018.

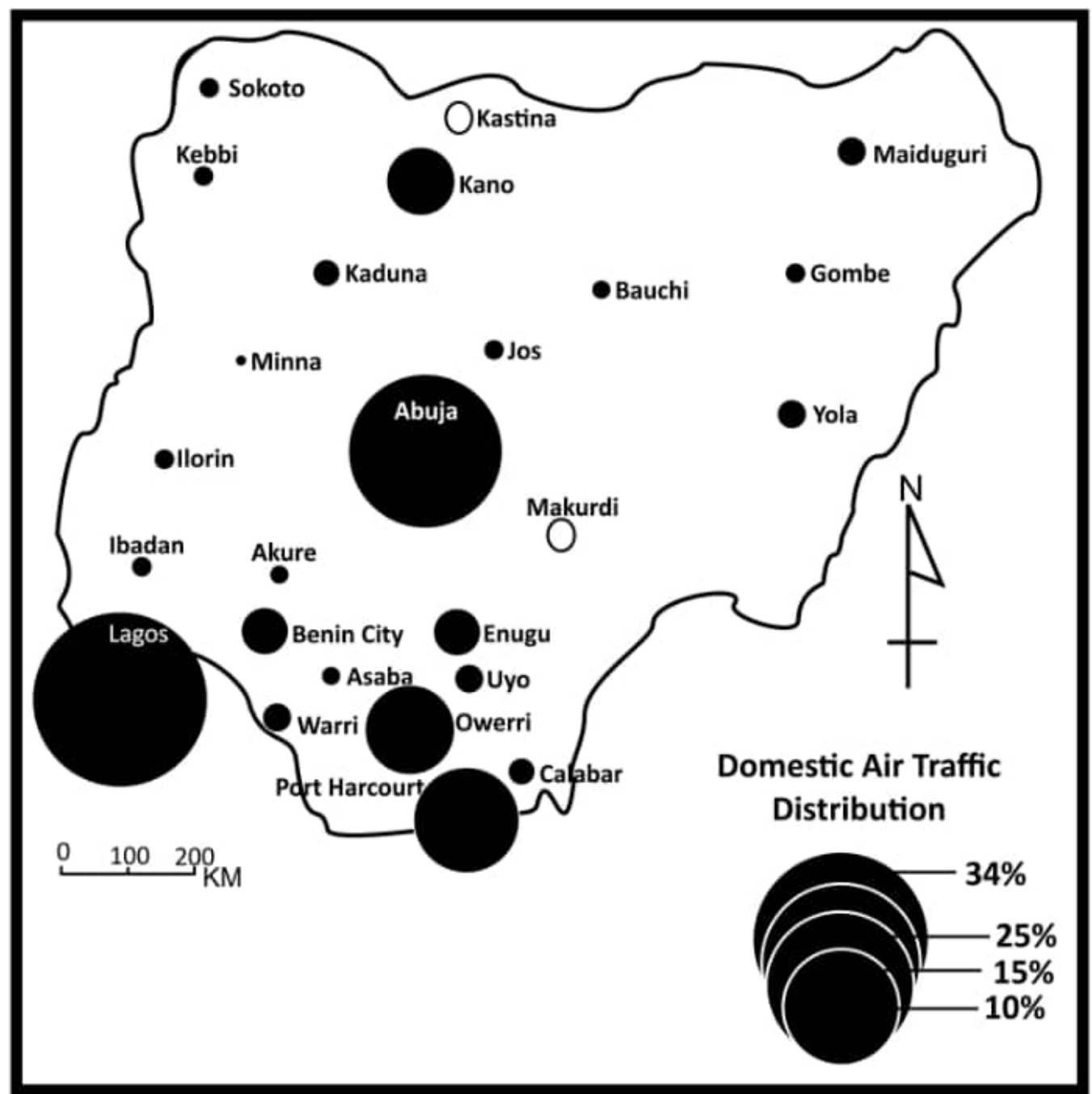

Source: Produced from NBS Air Transportation Data, 2018

A prominent aspect of domestic air passenger traffic generation in Nigeria is the dominance of Lagos during the study periods, as it accounted for $39.09 \%, 43.75 \%, 40.60 \%, 37.3 \%$ and $33.88 \%$ of the total domestic air passenger traffic in 2003, 2006, 2010, 2014 and 2018 respectively. Lagos is, therefore, the most dominant domestic air passenger traffic generating centre in Nigeria. This finding is similar to the findings by Filani, 1975 and Bardi, 1987. Filani (1975), in his study of the structural characteristics of domestic air transport in Nigeria, found Lagos to be a dominant airport in domestic air passenger traffic generation in 1960/61, $1965 / 66$ and $1971 / 72$ periods, when it accounted for $28.1 \%, 39.7 \%$ and $35.1 \%$ of Nigeria's total domestic air passenger traffic respectively. Bardi (1987) also found that Lagos played a dominant role in domestic air passenger traffic generation in 1980, 1983 and 1986, when it accounted for $45 \%, 46 \%$ and $48 \%$ of Nigeria's total domestic air passenger traffic respectively. 
Another noticeable aspect of domestic air passenger traffic generation in Nigeria is the pattern where the distribution of traffic tended more towards concentration than dispersal. In 2003, the six centres in the category of heavy traffic generation centres handled $90.43 \%$ of the total domestic air passenger traffic. The remaining 15 centres handled only $9.57 \%$ of the passengers. In 2006, the six-heavy traffic generating centres handled $80.1 \%$ of the total domestic air passenger traffic while the remaining 15 centres handled only $19.9 \%$. In 2010, the six-heavy generating centres handled $89.3 \%$ of the traffic, leaving only $10.7 \%$ for the remaining 15 centres. In 2014, the six-heavy traffic generating centres handled $84.08 \%$ while the remaining 17 centres handled $15.92 \%$ and in 2018 the six centres in the category of heavy traffic generating centres handled $83.31 \%$ while the remaining 17 centres handled $16.69 \%$. These patterns of domestic air passenger traffic generation are shown in Figure 7.

Figure 7. Patterns of Domestic Air Passenger Traffic Generation, 2003, 2006, 2010, 2014 and 2018

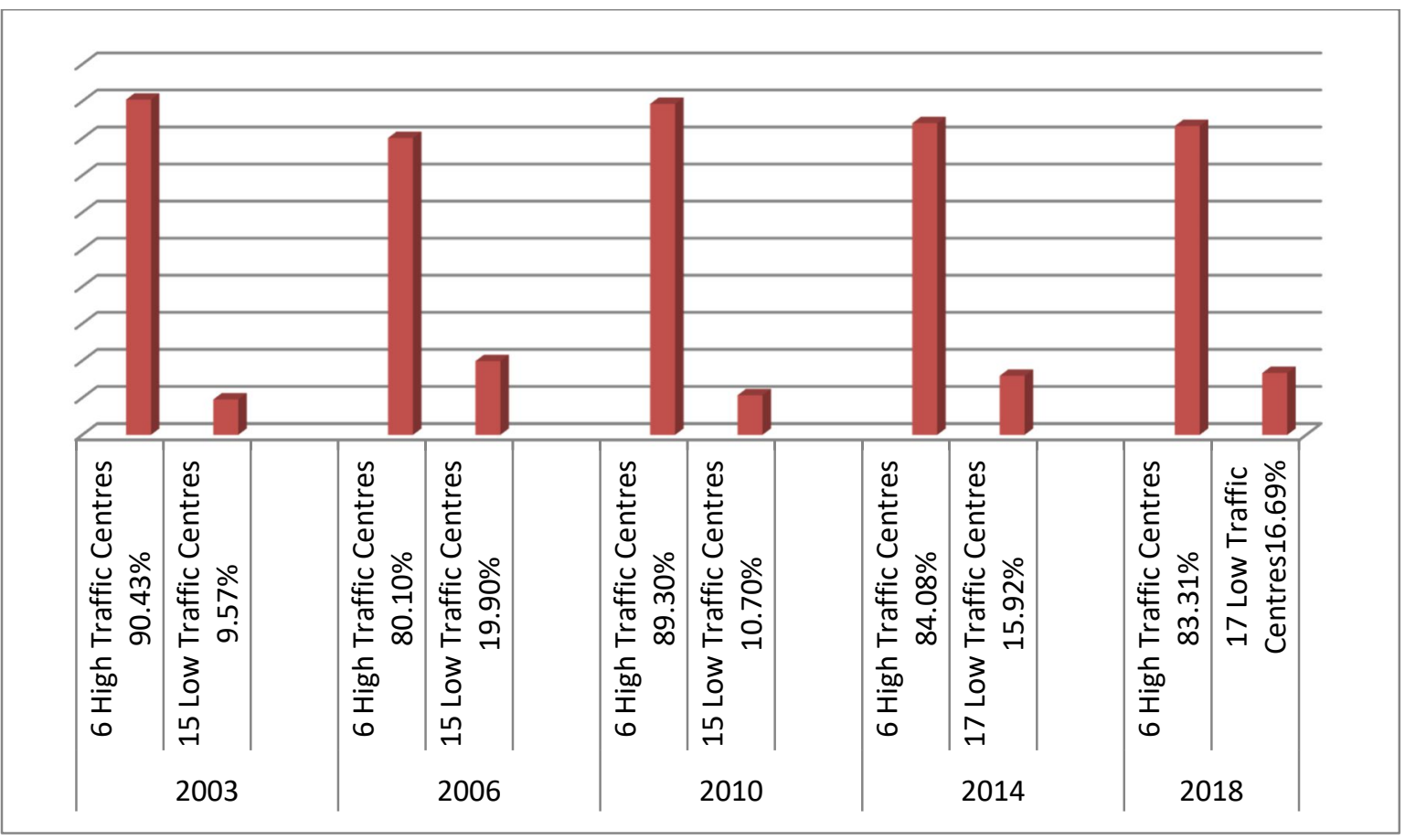

Source: Produced from NCAA Statistical Data for 2003, 2006, 2010, 2014 and NBS Air Transportation Data, 2018.

It can, therefore, be concluded that domestic air passenger traffic generation concentrated in few centres which generated most of the traffic during the 2003, 2006, 2010, 2014 and 2018 periods; and this suggests that only few airports in Nigeria (the six that generated heavy traffic each year) were viable during the study periods. The few traffic generated by the other airports seemed inadequate to keep them thriving without their operations being subsidized with the revenue from the more viable airports. 
Most centres were found to be low traffic generating centres presumably because of their low level of involvement in commercial and industrial activities which could not support high level of spatial interaction among them and other cities in Nigeria. However, Ibadan, with its high population and high level of commercial and industrial activities, generated low domestic air passenger traffic during the study periods (see Tables 1-5). This probably resulted from the 'traffic shadow effect' created by its nearness to Lagos which is a heavy traffic generating centre, and the presence of good network of roads, including the Lagos Ibadan highway that provides competitive alternatives to potential air travelers.

There were spatial and temporal changes in the volumes and patterns of domestic air passenger traffic generation in Nigeria. The volumes of traffic generated by the cities in the domestic air network varied from city to city as can be seen in Tables 1, 2, 3, 4 and 5 and in Figures 2, 3, 4, 5 and 6 . However, Lagos retained its $1^{\text {st }}$ position as the most dominant domestic air passenger traffic generating centre throughout the periods of study. The volumes of the total traffic generated by the six-heavy traffic generating centres each year also varied from year to year. There were changes in the list of cities with high traffic generating capacity over the study periods. For example, Kano was listed among the cities with high generating capacity in 2003 and 2006 but was replaced by Calabar in 2010. Warri and Enugu were also among the cities in 2003, 2006 and 2010 but were replaced by Owerri and Uyo in 2014 and in 2018 Uyo was replaced by Enugu. However, the pattern of traffic generation, where few centres generated most of the domestic air passenger traffic remained the same during the study periods.

\subsection{Relationship between the Populations of the Interacting Cities and the Volumes of Domestic Air Passenger Traffic Generated by the Cities}

The relationships between the population of each city and the total traffic generated by each city within the air transport system in Nigeria in 2003, 2006, 2010, 2014 and 2018 were established using the Pearson's Product Moment Correlation Coefficient ( $r$ ). The SPSS Version 22 was used for the computation. The population of each city and the total traffic handled by each city for the study periods, as shown in Tables 6, 7, 8, 9 and 10 were used for the analyses. The populations of the cities were represented as independent variable $(X)$ while the volumes of the total traffic handled by the cities were represented as dependent variable $(Y)$.In order to reduce the effects of large ranges in the data set and achieve better linear relationship, the data of both $X$ and $Y$ axes were transformed to logarithms ( $\log X$ and $\log Y$ ). 
Table 6. Population of the Cities and the Total Traffic Handled by each City within the Domestic Air Transport System in 2003

\begin{tabular}{|c|c|c|c|c|c|c|}
\hline S/NO & CITY & POPULATION & $\begin{array}{c}\text { POPULATION } \\
\text { ESTIMATE (X) }\end{array}$ & $\begin{array}{c}\text { TOTAL TRAFFIC } \\
\text { HANDLED (Y) }\end{array}$ & Log X & Log Y \\
\hline & & $\mathbf{1 9 9 1}$ & $\mathbf{2 0 0 3}$ & $\mathbf{2 0 0 3}$ & & \\
\hline 1. & ABUJA & 371,674 & 545,671 & $1,416,006$ & 5.74 & 6.15 \\
\hline 2. & AKURE & 239,124 & 351,069 & 3,037 & 5.54 & 3.48 \\
\hline 3. & BAUCHI & 206,537 & 303,226 & 1,759 & 5.48 & 3.25 \\
\hline 4. & BENIN & 762,719 & $1,119,782$ & 70,733 & 6.05 & 4.85 \\
\hline 5. & CALABAR & 310,839 & 456,357 & 121,939 & 5.66 & 5.09 \\
\hline 6. & ENUGU & 407,756 & 598,645 & 204,016 & 5.78 & 5.31 \\
\hline 7. & IBADAN & $1,835,300$ & $2,694,487$ & 5,060 & 6.43 & 3.70 \\
\hline 8. & ILORIN & 532,089 & 781,184 & 5,888 & 5.89 & 3.77 \\
\hline 9. & JOS & 510,300 & 749,195 & 44,079 & 5.87 & 4.64 \\
\hline 10. & KADUNA & 993,642 & $1,458,811$ & 123,414 & 6.16 & 5.09 \\
\hline 11. & KANO & $2,166,554$ & $3,180,816$ & 167,060 & 6.50 & 5.22 \\
\hline 12. & KATSINA & 259,315 & 380,712 & 1,757 & 5.58 & 3.24 \\
\hline 13. & LAGOS & $5,195,247$ & $9,131,630$ & $2,308,770$ & 6.96 & 6.36 \\
\hline 14. & MAIDUGURI & 618,278 & 907,722 & 69,493 & 5.96 & 4.84 \\
\hline 15. & MAKURDI & 151,515 & 222,446 & 2,509 & 5.35 & 3.40 \\
\hline 16. & MINNA & 189,191 & 273,724 & 4,821 & 5.44 & 3.68 \\
\hline 17. & OWERRI & 119,711 & 175,753 & 45,104 & 5.24 & 4.65 \\
\hline 18. & PORT HARCOURT & 703,421 & $1,032,724$ & 852,521 & 6.01 & 5.93 \\
\hline 19. & SOKOTO & 329,639 & 483,958 & 21,784 & 5.68 & 4.34 \\
\hline 20. & WARRI & 363,382 & 533,498 & 391,915 & 5.73 & 5.59 \\
\hline 21. & YOLA & 54,810 & 80,469 & 45,915 & 4.91 & 4.67 \\
\hline
\end{tabular}

Source: NCAA Statistical Data, 2003 for the Traffic Data, NPC for the 1991 Census Figures on which the Estimates were based.

Table 7. Population of the Cities and the Total Traffic Handled by each City within the Domestic Air Transport System in 2006

\begin{tabular}{|c|c|c|c|c|c|c|}
\hline S/NO. & CITY & POPULATION & $\begin{array}{c}\text { POPULATION } \\
\text { ESTIMATE (X) }\end{array}$ & $\begin{array}{c}\text { TOTAL TRAFFIC } \\
\text { HANDLED (Y) }\end{array}$ & Log X & Log $\mathbf{~}$ \\
\hline & & $\mathbf{1 9 9 1}$ & $\mathbf{2 0 0 6}$ & $\mathbf{2 0 0 6}$ & & \\
\hline 1. & ABUJA & 371,674 & $1,406,239$ & $1,607,421$ & 6.15 & 6.21 \\
\hline 2. & AKURE & 239,124 & 386,442 & 3,036 & 5.59 & 3.48 \\
\hline 3. & BAUCHI & 206,537 & 333,779 & 1,152 & 5.52 & 3.06 \\
\hline 4. & BENIN & 762,719 & $1,232,611$ & 91,456 & 6.01 & 4.96 \\
\hline 5. & CALABAR & 310,839 & 502,339 & 166,754 & 5.70 & 5.22 \\
\hline 6. & ENUGU & 407,756 & 658,964 & 191,441 & 5.82 & 5.28 \\
\hline 7. & IBADAN & $1,835,300$ & $2,965,981$ & 12,242 & 6.47 & 4.09 \\
\hline 8. & ILORIN & 532,089 & 859,895 & 19,223 & 5.93 & 4.28 \\
\hline 9. & JOS & 510,300 & 824,683 & 30,758 & 5.92 & 4.49 \\
\hline 10. & KADUNA & 993,642 & $1,605,779$ & 109,161 & 6.21 & 5.04 \\
\hline 11. & KANO & $2,166,554$ & $3,501,315$ & 154,657 & 6.54 & 5.19 \\
\hline 12. & KATSINA & 259,315 & 419,072 & 405 & 5.62 & 2.61 \\
\hline 13. & LAGOS & $5,195,247$ & $10,514,383$ & $2,849,760$ & 7.02 & 6.45 \\
\hline 14. & MAIDUGURI & 618,278 & 999,183 & 30,682 & 6.00 & 4.49 \\
\hline 15. & MAKURDI & 151,515 & 244,860 & 242 & 5.39 & 2.38 \\
\hline 16. & MINNA & 189,191 & 307,747 & 7,496 & 5.49 & 3.87 \\
\hline 17. & OWWERRI & 119,711 & 193,462 & 315,599 & 5.27 & 5.50 \\
\hline 18. & PORT HARCOURT & 703,421 & $1,136,781$ & 573,807 & 6.06 & 5.76 \\
\hline 19. & SOKOTO & 329,639 & 532,721 & 45,929 & 5.73 & 4.66 \\
\hline 20. & WARRI & 363,382 & 587,252 & 248,737 & 5.77 & 5.40 \\
\hline 21. & YOLA & 54,810 & 88,577 & 53,547 & 4.95 & 4.73 \\
\hline
\end{tabular}

Source: NCAA Statistical Data, 2006 for the Traffic Data. NPC for the 1991 Census Figures on which the estimates were based. 
Table 8. Population of the Cities and the Total Traffic Handled by each City within the Domestic Air Transport System in 2010

\begin{tabular}{|c|c|c|c|c|c|c|}
\hline S/NO. & CITY & POPULATION & $\begin{array}{c}\text { POPULATION } \\
\text { ESTIMATE (X) }\end{array}$ & $\begin{array}{c}\text { TOTAL TRAFFIC } \\
\text { HANDLED (Y) }\end{array}$ & Log X & Log Y \\
\hline & & $\mathbf{1 9 9 1}$ & $\mathbf{2 0 1 0}$ & $\mathbf{2 0 1 0}$ & & \\
\hline 1. & ABUJA & 371,674 & $2,015,604$ & $1,643,838$ & 6.30 & 6.22 \\
\hline 2. & AKURE & 239,124 & 439,212 & 2,766 & 5.64 & 3.44 \\
\hline 3. & BENIN & 762,719 & $1,400,927$ & 154,558 & 6.15 & 5.19 \\
\hline 4. & CALABAR & 310,839 & 570,935 & 125,418 & 5.76 & 5.10 \\
\hline 5. & ENUGU & 407,756 & 784,948 & 11,875 & 5.89 & 4.07 \\
\hline 6. & IBADAN & $1,835,300$ & $3,370,995$ & 17,976 & 6.53 & 4.25 \\
\hline 7. & ILORIN & 532,089 & 997,317 & 23,714 & 6.00 & 4.38 \\
\hline 8. & JOS & 510,300 & 937,296 & 37,064 & 5.97 & 4.57 \\
\hline 9. & KADUNA & 993,642 & $1,825,076$ & 83,931 & 6.26 & 4.92 \\
\hline 10. & KANO & $2,166,554$ & $3,979,427$ & 124,963 & 6.60 & 5.10 \\
\hline 11. & KATSINA & 259,315 & 476,298 & 5,262 & 5.68 & 3.72 \\
\hline 12. & LAGOS & $5,195,247$ & $12,689,110$ & $2,161,264$ & 7.10 & 6.33 \\
\hline 13. & MAIDUGURI & 618,278 & $1,135,625$ & 47,301 & 6.06 & 4.67 \\
\hline 14. & MINNA & 189,191 & 347,497 & 950 & 5.54 & 2.98 \\
\hline 15. & OWERRI & 119,711 & 219,880 & 208,267 & 5.34 & 5.32 \\
\hline 16. & PORT HARCOURT & 703,421 & $1,292,011$ & 464,945 & 6.11 & 5.67 \\
\hline 17. & SOKOTO & 329,639 & 605,466 & 29,188 & 5.78 & 4.47 \\
\hline 18. & WARRI & 363,382 & 667,443 & 69,894 & 5.82 & 4.84 \\
\hline 19. & YOLA & 54,810 & 100,672 & 51,440 & 5.00 & 4.71 \\
\hline 20. & GOMBE & 163,604 & 300,500 & 5,224 & 5.48 & 3.72 \\
\hline 21. & UYO & 58,269 & 107,210 & 53,199 & 5.03 & 4.73 \\
\hline
\end{tabular}

Source: NCAA Statistical Data, 2010 for the Traffic Data. NPC for the 1991 Census Figures on which the Estimates were based.

TABLE 9. Population of the Cities and the Total Traffic Handled by each City within the Domestic Air Transport System in 2014

\begin{tabular}{|c|c|c|c|c|c|c|}
\hline S/NO. & CITY & POPULATION & $\begin{array}{c}\text { POPULATION } \\
\text { ESTIMATE (X) }\end{array}$ & $\begin{array}{c}\text { TOTAL TRAFFIC } \\
\text { HANDLE (Y) }\end{array}$ & Log X & Log Y \\
\hline & & $\mathbf{1 9 9 1}$ & $\mathbf{2 0 1 4}$ & $\mathbf{2 0 1 4}$ & & \\
\hline 1. & ABUJA & 371,674 & $5,424,462$ & $3,367,969$ & 6.73 & 6.53 \\
\hline 2. & AKURE & 239,124 & 499,188 & 6,920 & 5.70 & 3.84 \\
\hline 3. & ASABA & 49,725 & 103,804 & 170,847 & 5.02 & 5.23 \\
\hline 4. & BAUCHI & 206,537 & 431,160 & 16,988 & 5.63 & 4.23 \\
\hline 5. & BENIN & 762,719 & $1,592,229$ & 234,185 & 6.20 & 5.37 \\
\hline 6. & CALABAR & 310,839 & 648,898 & 201,221 & 5.81 & 5.30 \\
\hline 7 & ENUGU & 407,756 & 851,314 & 287,521 & 5.93 & 5.46 \\
\hline 8 & GOMBE & 163,604 & 341,534 & 31,370 & 5.53 & 4.50 \\
\hline 9. & IBADAN & $1,835,300$ & $3,831,314$ & 75,464 & 6.58 & 4.88 \\
\hline 10. & ILORIN & 532,089 & $1,110,772$ & 85,990 & 6.05 & 4.93 \\
\hline 11. & JOS & 510,300 & $1,065,290$ & 66,435 & 6.03 & 4.82 \\
\hline 12. & KADUNA & 993,642 & $2,074,269$ & 192,427 & 6.32 & 5.28 \\
\hline 13. & KANO & $2,166,554$ & $4,522,829$ & 292,301 & 6.66 & 5.47 \\
\hline 14. & KEBBI & 63,147 & 131,823 & 2,065 & 5.12 & 3.31 \\
\hline 15. & LAGOS & $5,195,247$ & $22,452,066$ & $4,349,371$ & 7.35 & 6.64 \\
\hline 16. & MAIDUGURI & 618,278 & $1,290,697$ & 19,766 & 6.11 & 4.30 \\
\hline
\end{tabular}




\begin{tabular}{|c|c|c|c|c|c|c|}
\hline 17. & MINNA & 189,191 & 316,299 & 3,475 & 5.50 & 3.54 \\
\hline 18. & OWERRI & 119,711 & 249,905 & 320,681 & 5.40 & 5.51 \\
\hline 19. & PORT HARCOURT & 703,421 & $1,468,440$ & $1,225,022$ & 6.17 & 6.09 \\
\hline 20. & SOKOTO & 329,639 & 688,144 & 99,645 & 5.84 & 5.00 \\
\hline 21. & UYO & 58,369 & 121,848 & 292,361 & 5.09 & 5.47 \\
\hline 22. & WARRI & 363,382 & 758,584 & 217,367 & 5.88 & 5.34 \\
\hline 23. & YOLA & 54,810 & 114,420 & 154,547 & 5.06 & 5.19 \\
\hline
\end{tabular}

Source: NCAA Statistical Data, 2014 for the Traffic Data. NPC for the 1991 Census Figures on which the Estimates were based.

Table 10. Population of the Cities and the Total Traffic Handled by each City within the Domestic Air Transport System in 2018

\begin{tabular}{|c|c|c|c|c|c|c|}
\hline S/NO. & CITY & POPULATION & $\begin{array}{c}\text { POPULATION } \\
\text { ESTIMATE (X) }\end{array}$ & $\begin{array}{c}\text { TOTAL TRAFIC } \\
\text { HANDLED (Y) }\end{array}$ & Log X & Log Y \\
\hline & & $\mathbf{1 9 9 1}$ & $\mathbf{2 0 1 8}$ & $\mathbf{2 0 1 8}$ & & \\
\hline 1. & ABUJA & 371,674 & $4,577,998$ & $3,863,083$ & 6.66 & 6.59 \\
\hline 2. & AKURE & 239,124 & 567,353 & 62,386 & 5.75 & 4.80 \\
\hline 3. & ASABA & 49,725 & 117,979 & 65,864 & 5.07 & 4.82 \\
\hline 4. & BAUCHI & 206,537 & 490,036 & 36,140 & 4.69 & 4.56 \\
\hline 5. & BENIN & 762,719 & $1,809,652$ & 320,199 & 6.26 & 5.51 \\
\hline 6. & CALABAR & 310,839 & 737,507 & 166,152 & 5.87 & 5.22 \\
\hline 7 & ENUGU & 407,756 & 967,455 & 341,039 & 5.99 & 5.53 \\
\hline 8 & GOMBE & 163,604 & 388,172 & 56,403 & 5.59 & 4.75 \\
\hline 9. & IBADAN & $1,835,300$ & $4,354,492$ & 92,100 & 6.64 & 4.96 \\
\hline 10. & ILORIN & 532,089 & $1,264,452$ & 113,967 & 6.10 & 5.06 \\
\hline 11. & JOS & 510,300 & $1,210,754$ & 76,950 & 7.09 & 4.89 \\
\hline 12. & KADUNA & 993,642 & $2,357,547$ & 168,948 & 6.37 & 5.23 \\
\hline 13. & KANO & $2,166,554$ & $5,140,436$ & 407,392 & 6.71 & 5.61 \\
\hline 14. & KEBBI & 63,147 & 149,825 & 30,185 & 5.18 & 4.48 \\
\hline 15. & LAGOS & $5,195,247$ & $18,481,018$ & $4,245,147$ & 7.27 & 6.63 \\
\hline 16. & MAIDUGURI & 618,278 & $1,466,946$ & 201,940 & 6.17 & 5.31 \\
\hline 17. & MINNA & 189,191 & 448,881 & 2,698 & 5.65 & 3.43 \\
\hline 18. & OWERRI & 119,711 & 284,030 & 510,546 & 5.45 & 5.71 \\
\hline 19. & PORT HARCOURT & 703,421 & $1,668,959$ & $1,072,978$ & 6.22 & 6.03 \\
\hline 20. & SOKOTO & 329,639 & 782,112 & 107,245 & 5.89 & 5.05 \\
\hline 21. & UYO & 58,369 & 138,488 & 232,827 & 5.14 & 5.37 \\
\hline 22. & WARRI & 363,382 & 862,172 & 175,072 & 5.94 & 5.24 \\
\hline 23. & YOLA & 54,810 & 130,044 & 182,010 & 5.11 & 5.26 \\
\hline & & & & & \\
\hline
\end{tabular}

Source: NBS Transportation Data, 2018 for the Traffic Data. NPC for the 1991 Census Figures on which the Estimates were based.

The results of the correlation analyses are shown in Table 11. 
Table 11. Summary of Correlation Results of the Analysis of the Relationships between the Population of each City and the Traffic Generated by each City

\begin{tabular}{|cccc} 
Year Correlation & $\begin{array}{c}\text { Coefficient of } \\
\text { Coefficient } \\
(\mathbf{r})\end{array}$ & $\begin{array}{c}\text { Determination } \\
\left(\mathbf{r}^{2}\right)\end{array}$ & $\begin{array}{c}\text { Significant } \\
\text { at }\end{array}$ \\
\hline $\mathbf{2 0 0 3}$ & 0.451 & 0.203 & 0.020 (1 tailed) \\
$\mathbf{2 0 0 6}$ & 0.480 & 0.230 & 0.014 (1 tailed) \\
$\mathbf{2 0 1 0}$ & 0.480 & 0.230 & 0.014 (1 tailed) \\
$\mathbf{2 0 1 4}$ & 0.533 & 0.284 & 0.004 (1 tailed) \\
$\mathbf{2 0 1 8}$ & 0.506 & 0.256 & 0.007 (1 tailed)
\end{tabular}

A test of significance of the correlation coefficient was made using the Hypotheses below:

Ho: There is no significant relationship between the population of a city in Nigeria and the volume of domestic air passenger traffic generated by the city.

$\mathrm{H}_{\mathrm{I}}$ : There is a significant relationship between the population of a city in Nigeria and the volume of domestic air passenger traffic generated by the city.

In testing the significance of the correlation coefficient, a version of the Student's ' $t$ ' test as given below, and the correlation results for year $2018-r=0.506$ were used -

$$
t=\frac{\sqrt[r]{n-2}}{\sqrt{1-r^{2}}}
$$

Where $r$ is the value of the correlation coefficient, and $n$ the population size.

The value of the calculated ' $t$ ' is 2.687 . At 0.05 level of significance and $21^{\circ}$ of freedom, the critical value of ' $t$ ' from the table of Student's ' $t$ ' distribution is 1.72. Since the calculated value of ' $\mathrm{t}$ ' is greater than the value of the table ' $\mathrm{t}$ ' of 1.72 the null hypothesis ( $\mathrm{Ho}$ ) is rejected and the alternate hypothesis $\left(\mathrm{H}_{\mathrm{I}}\right)$ is accepted. There is, therefore, a significant relationship between the population of a city in Nigeria and the volume of domestic air passenger traffic generated by the city. As can be seen from Table 11, the results of the analyses show that the population of each city correlated positively and significantly with the volume of traffic generated by each city in 2003, 2006, 2010, 2014 and 2018.

The $r$ values of $0.451,0.480,0.480,0.533$ and 0.506 for 2003, 2006, 2010, 2014 and 2018 respectively show that there were statistically, weak, positive relationships between the populations of the interacting cities and the volumes of domestic air passenger traffic generated by the cities. Even though the positive relationships were weak, they were 
statistically significant. The values of the calculated ' $t$ ' are 2.202, 2.385, 2.385, 2.888 and 2.687 for 2003, 2006, 2010, 2014 and 2018 respectively. At 0.05 levels of significance and $19^{\circ}$ of Freedom for 2003, 2006, and 2010; and $21^{\circ}$ of freedom for 2014 and 2018 the critical values of ' $t$ ' from the Table of Student's ' $t$ ' Distribution are 1.73 for 2003, 2006 and 2010 and 1.72 for 2014 and 2018. Since the values of the calculated ' $t$ ' during the study periods are greater than the values of the Table ' $t$ ' there is a statistically significant relationship between the population of a city in Nigeria and the volume of domestic air passenger traffic generated by the city. These relationships are shown in Figures 8, 9, 10, 11 and 12.

Figure 8. Relationship between the Populations of the Interacting Cities in Nigeria and the Volume of Domestic Air Passenger Traffic Generated by the Cities in 2003.

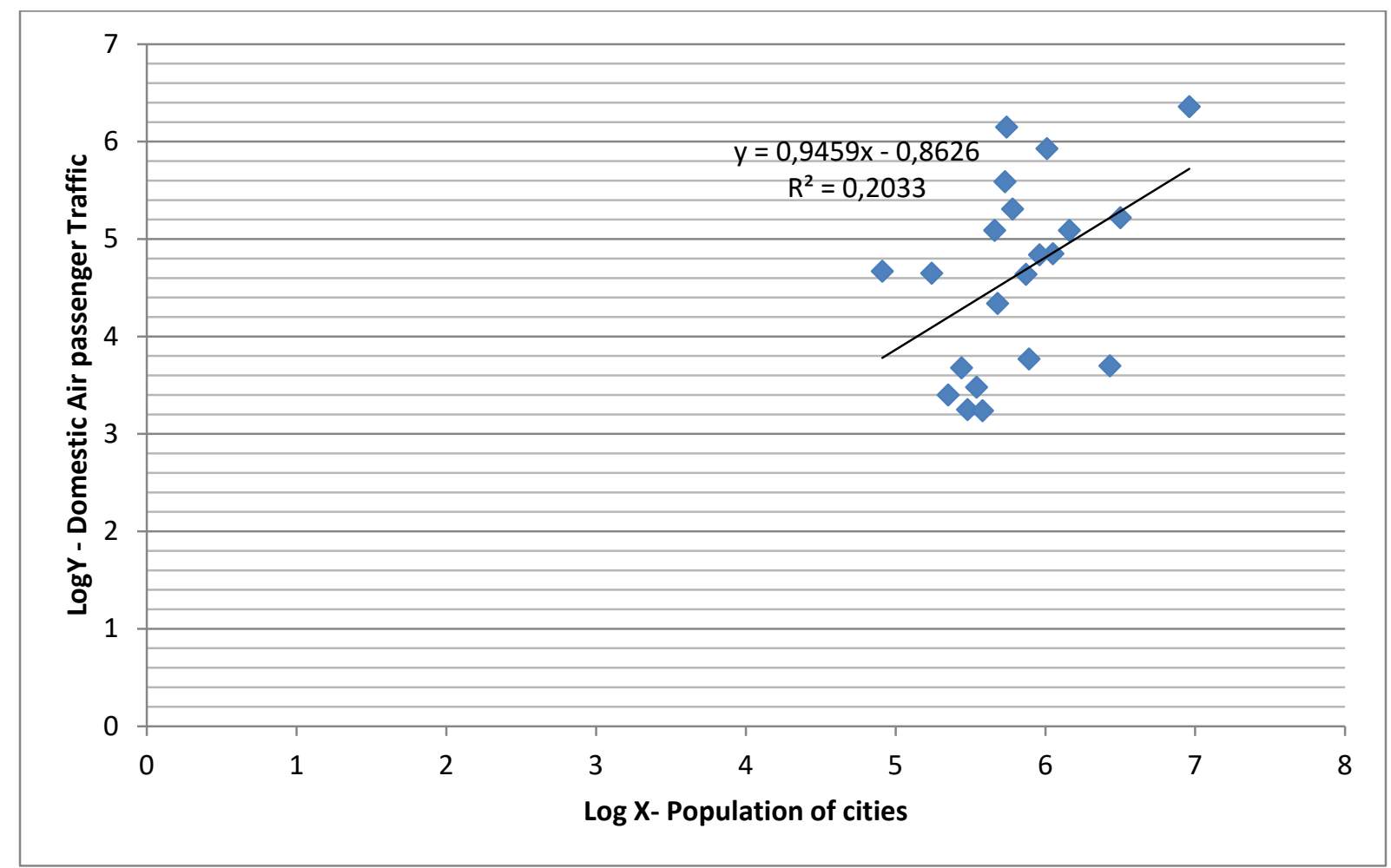

Source: Produced from NCAA Statistical Data for 2003 
Figure 9. Relationship between the Populations of the Interacting Cities in Nigeria and the Volumes of Domestic Air Passenger Traffic Generated by the Cities in 2006.

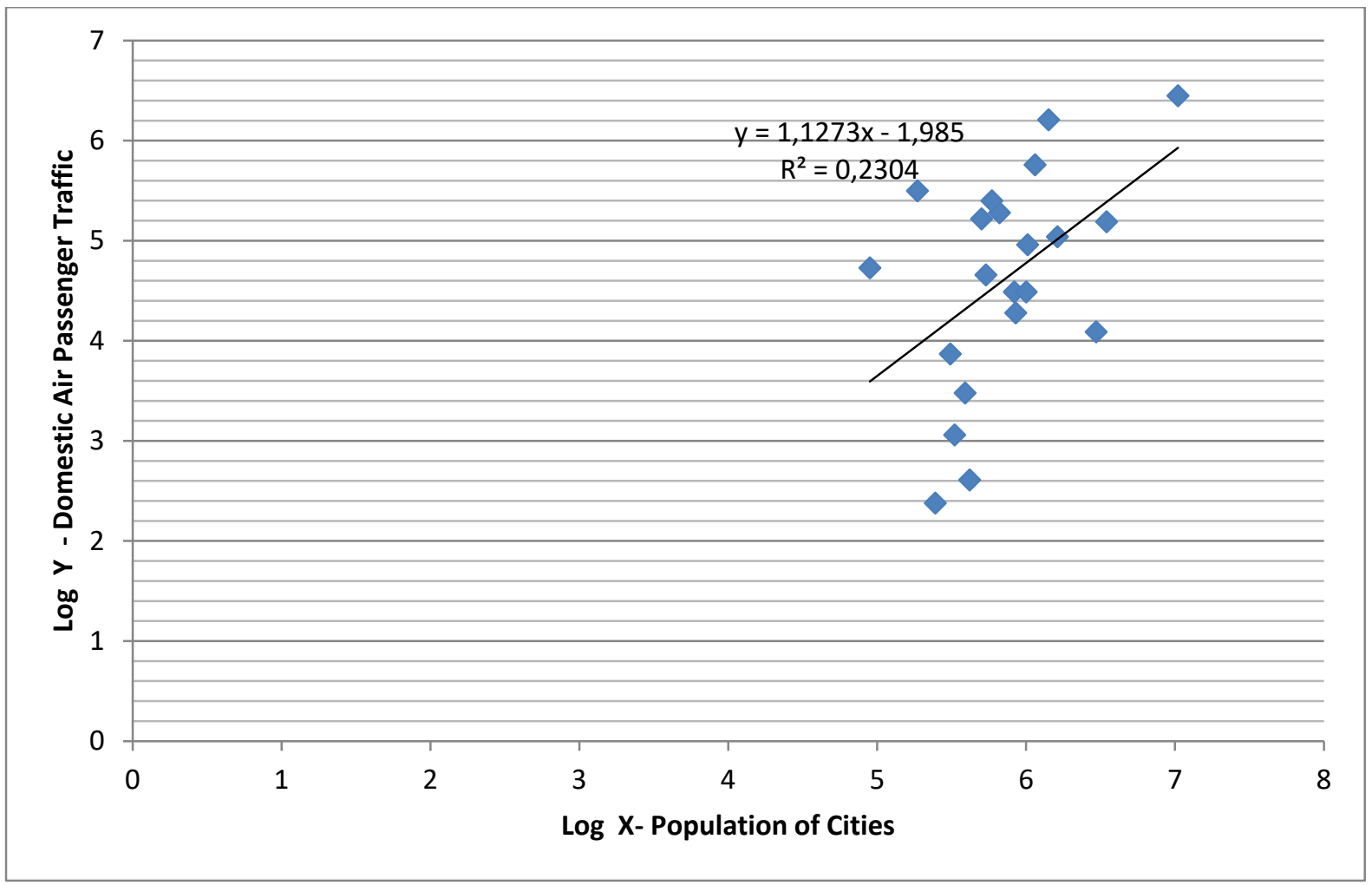

Source: Produced from NCAA Statistical Data for 2006.

Figure 10. Relationship between the Populations of the Interacting Cities in Nigeria and the Volumes of Domestic Air Passenger Traffic Generated by the Cities in 2010.

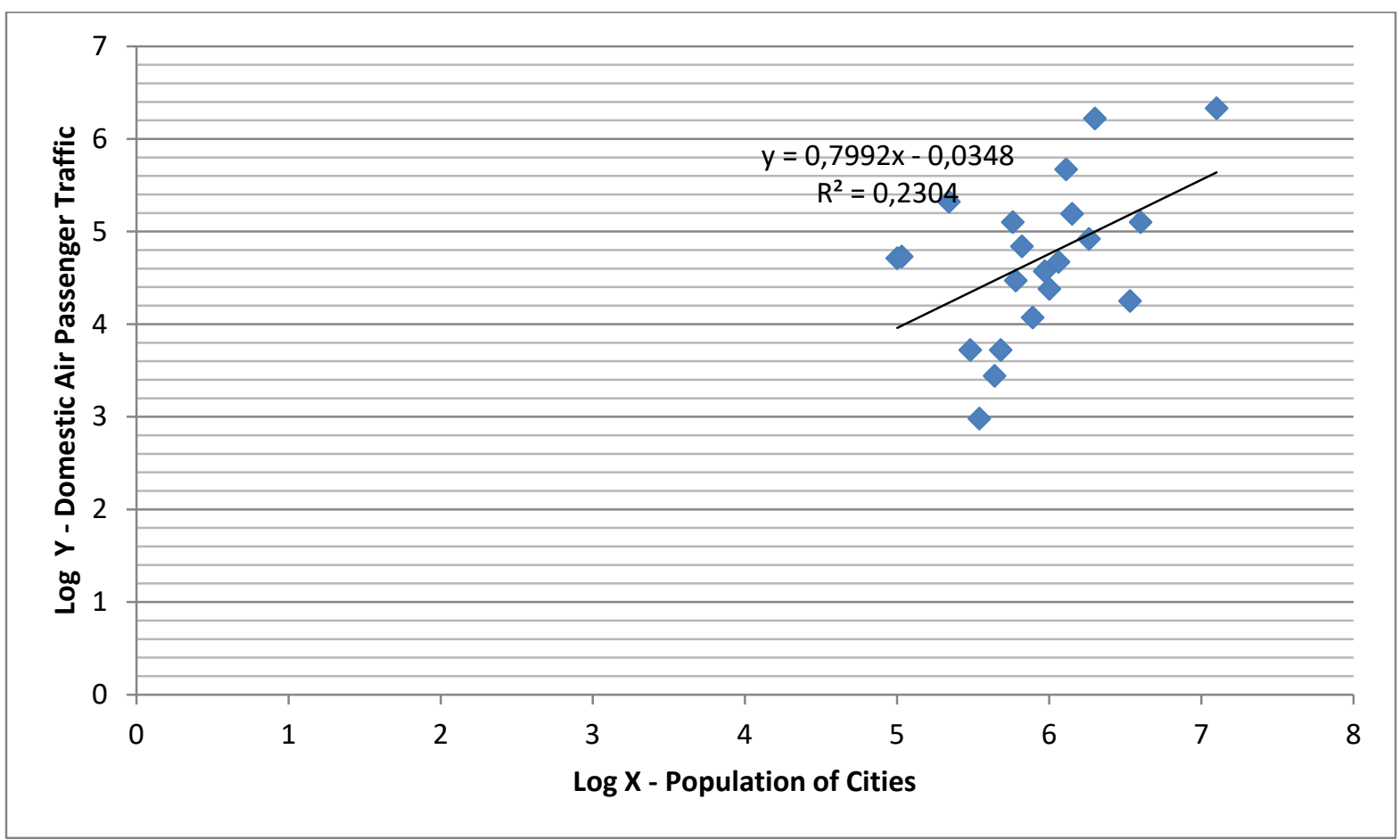

Source: Produced from NCAA Statistical Data for 2010. 
Figure 11. Relationship between the Populations of the Interacting Cities in Nigeria and the Volume of Domestic Air Passenger Traffic Generated by the Cities in 2014.

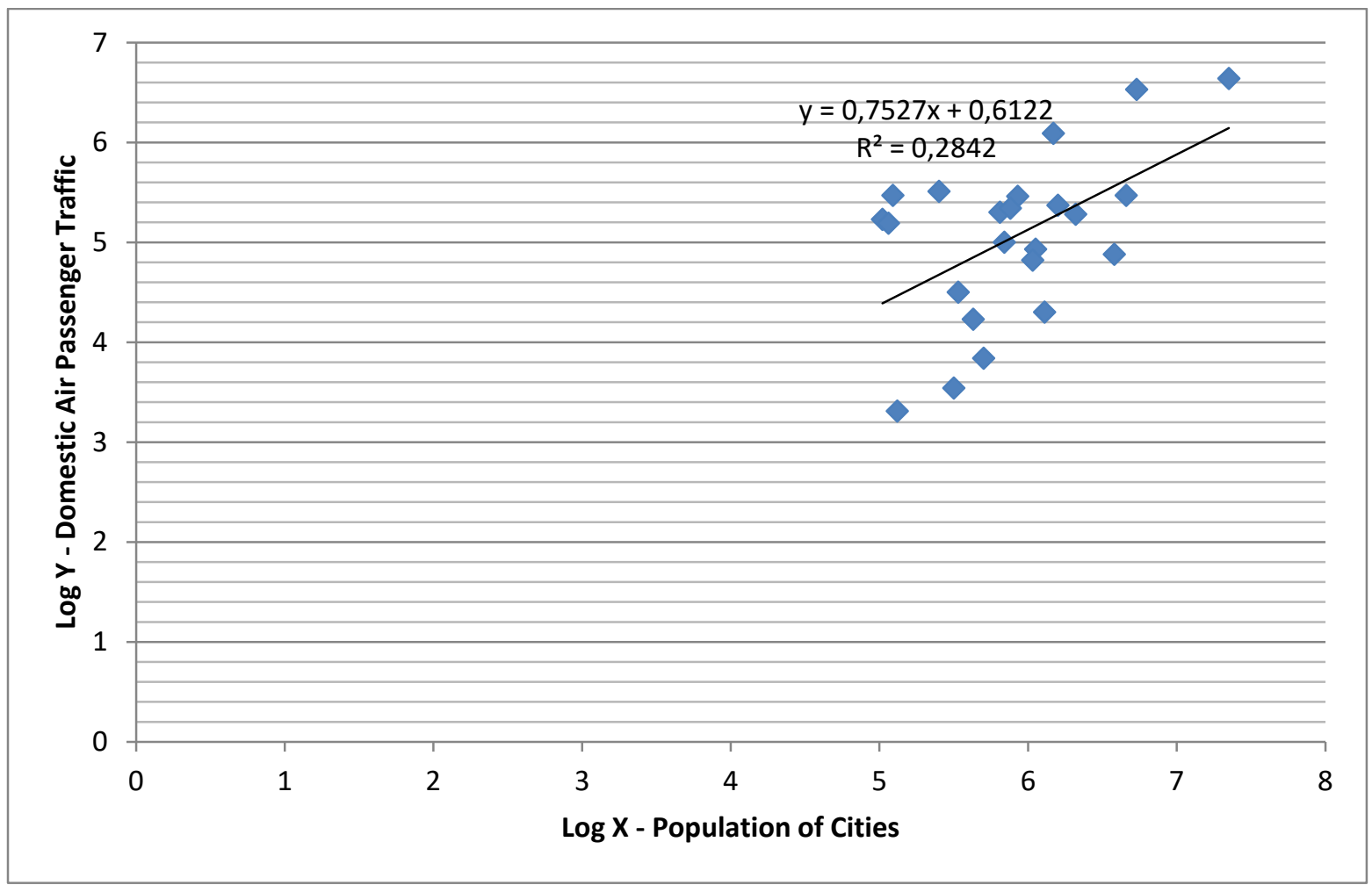

Source: Produced from NCAA Statistical Data for 2014.

Figure 12. Relationship between the Populations of the Interacting Cities in Nigeria and the Volume of Domestic Air Passenger Traffic Generated by the Cities in 2018.

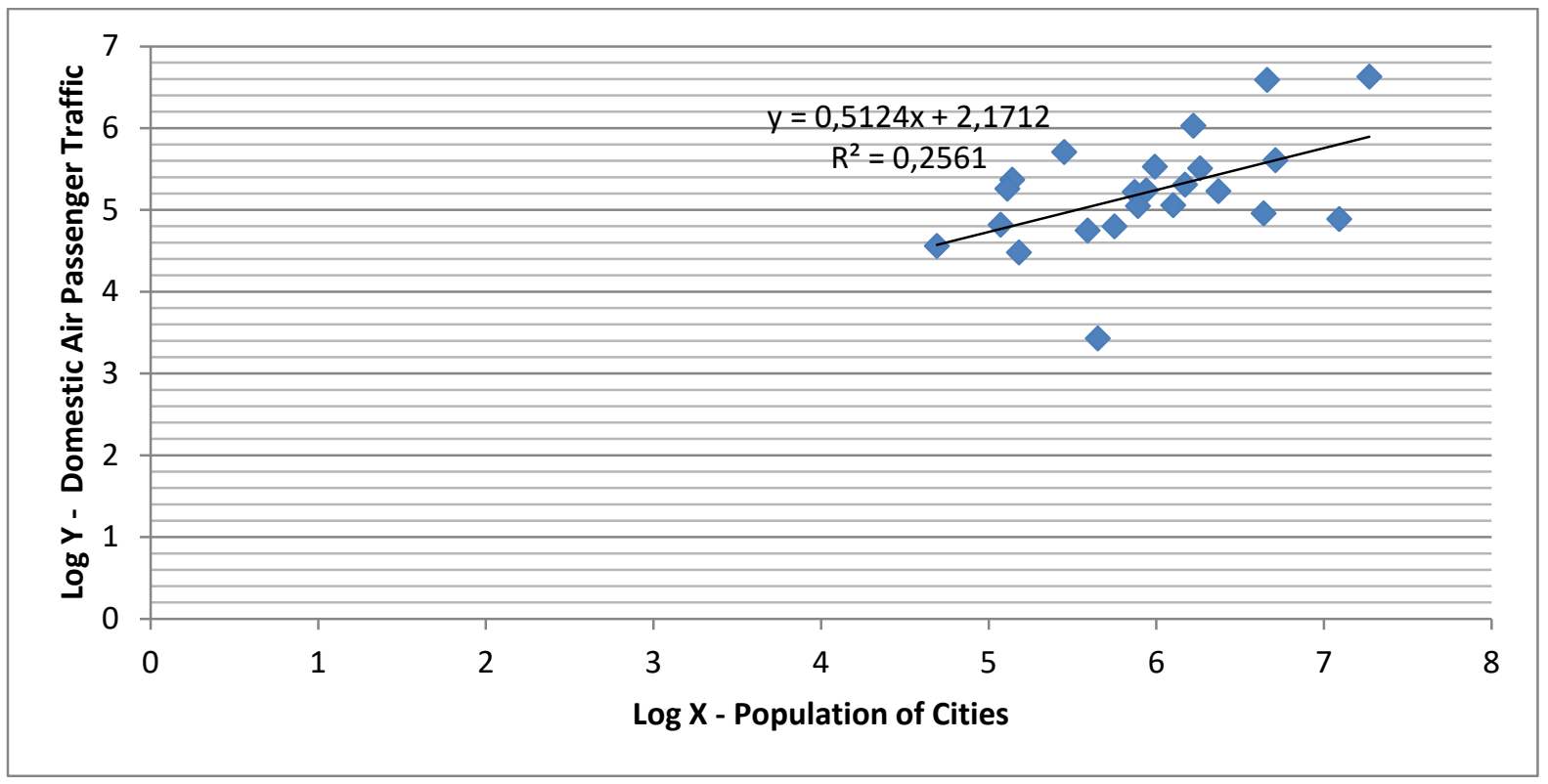

Source: Produced from NBS Air Transportation Data for 2018.

The $r^{2}$ values of $0.203,0.230,0.230,0.284$ and 0.256 for 2003, 2006, 2010, 2014 and 2018 respectively signifies that the population of the cities accounted for $20.3 \%, 23 \%, 23 \%, 28.4 \%$ 
and $25.6 \%$ of the domestic air passenger traffic in 2003, 2006, 2010, 2014 and 2018 respectively. This indicates that population significantly determined, to some extent, the volume of domestic air passenger traffic generated by the cities in Nigeria during the study periods. The finding of this research supports the findings of Alam and Karim (1997), which indicated among other things, that population was a significant variable in air travel in Bangladesh. The result is also supported by the study by Masumoto (2005), which indicated among others, that population was important in explaining air traffic flows in major Asian cities.

\section{CONCLUSION AND POLICY RECOMMENDATIONS}

This study analyzed the spatial pattern of domestic air passenger traffic generation in Nigeria and the relationship between the populations of the interacting city-pairs and the volumes of domestic air passenger traffic generated by the cities. The results of the study show that Lagos was the most dominant domestic air passenger traffic generating centre even when the political capital city of Nigeria has been moved from Lagos to Abuja since 1991.

The study also found that the generation of domestic air passenger traffic was concentrated in few centres. These centres in the category of heavy traffic generating centres - Lagos, Abuja, Port Harcourt, Warri, Enugu, Kano, Benin, Calabar and Owerri handled 90.43\%, 80.1\%, $89.3 \%, 84.08 \%$ and $83.31 \%$ in 2003, 2006, 2010, 2014 and 2018 respectively. This implies that only the few airports in the heavy traffic generating category were viable during the study periods. Most centres were found to be low traffic generating centres presumably because of their low level of involvement in commercial and industrial activities which could not support high level of spatial interaction among them and other cities in Nigeria.

The study established that there were spatial and temporal changes in the volumes and patterns of domestic air passenger traffic generation in Nigeria. The study also shows that there were statistically, positive relationships between the populations of the interacting cities and the volumes of domestic air passenger traffic generated by the cities, implying that population significantly determined the volume of domestic air passenger traffic generated by the cities in Nigeria during the study periods.

Since the generation of domestic air passenger traffic concentrated in few centres of high population concentration where administrative, industrial and commercial activities take place, it is pertinent to alter this pattern of traffic generation from concentration to dispersal. This could be achieved through balanced regional development where conscious effort is made to redistribute economic activities within the country. This, would in turn, increase the population of the centres where new economic activities have developed. The rational dispersal of 
economic activities and its attendant redistribution of population would help in changing the pattern of domestic air passenger traffic generation from concentration to dispersal and help in increasing the air passenger generating capacity of the cities and the connectivity of domestic air network in Nigeria.

It is not advisable for a country like Nigerian to concession the heavy traffic generating airports in the country to private companies for management as once suggested by some stake holders. If the airports in the heavy traffic generating capacity are concessioned to private companies whose interest is profit maximization, all other airports which apparently survive on the revenues obtained from the concessioned airports would not survive on their own as a result of low passenger traffic generating capacity and low revenue obtainable from their activities. This would then lead to the collapse of the low traffic generating airports and consequent total collapse of domestic air passenger transport in Nigeria if the private companies fail to perform effectively.

Rather than concession the heavy traffic generating airports to private companies, the government of Nigeria should aim at achieving spatial equilibrium in air passenger traffic generation by introducing deliberate policy of industrial dispersion and balanced regional development to stimulate resource development and growth of the low traffic generating cities/airports. This would help in redistribution of population and economic activities in the cities and improve their competitive positions in terms of development, growth and air passenger traffic generating capacity.

\section{REFERENCES}

- Abioye, O. (2008), Airports Handle 450 Flights Daily, The Punch, January 2, P.30.

- Abioye, O. (2009), Airports Handle 1,000 Flights Weekly, The Punch, January 12, P.17.

- Alam, J. B. And Karim, D. M. (1997), Air Travel Demand Model For Domestic Air Transportation In Bangladesh. Available Www.Geocities.Com/Totul91/Pdf/Lebpaper.Pdf, ( Accessed On 2/9/2018).

- Bardi, E. C. (1987), Intercity Air Passenger Traffic Flow In Nigeria. Unpublished M.Sc. Dissertation, Department of Geography and Planning, University of Lagos, Akoka, Lagos, Nigeria.

- Bardi, E. C. (2017) Spatial Structure and Growth Trend of Domestic Air Passenger Traffic In Nigeria. Unpublished Ph.D. Dissertation, Department of Geography, University Of Nigeria, Nsukka, Nigeria. 
- Cohen, S. (2016) A Gravity Model For Aviation Forecasting. Unpublished Master Of Science Dissertation, Department Of Spatial Transport And Environmental Economics, University Of Amsterdam.

- Federal Republic Of Nigeria (2004), Budget Of The Federal Republic Of Nigeria, 2004 Fiscal Year. Budget Office Of The Federation, Federal Ministry Of Finance, Abuja, Fct, Nigeria, P. 6.

- Federal Republic Of Nigeria (2007), Budget Of The Federal Republic Of Nigeria, 2007 Appropriation Act. Budget Office Of The Federal Government Of Nigeria, Federal Ministry Of Finance, Abuja, Fct, Nigeria. Available Www.Budget Office.Gov.Ng/Pdf/2007budget.Pdf (Accessed On 21/10/2018).

- Federal Republic Of Nigeria (2008), Budget Of The Federal Republic Of Nigeria, 2008 Appropriation Act. Budget Office Of The Federal Government Of Nigeria, Federal Ministry Of Finance, Abuja, Fct, Nigeria. Available: Www.Nigeriabudget.Com/Appact.Html (Accessed On 3/3/ 2019).

- Federal Republic Of Nigeria (2011), Budget Of The Federal Republic Of Nigeria, 2011. Budget Office Of The Federal Government Of Nigeria, Federal Ministry Of Finance, Abuja, Fct, Nigeria. Available Www.Budgetoffice.Gov.Ng/2011 Budget Approved.Html(Accessed On1/10/2018)

- Federal Republic Of Nigeria (2014), Budget Of The Federal Republic Of Nigeria, 2014. Budget Office Of The Federal Government Of Nigeria, Federal Ministry Of Finance, Abuja, Fct, Nigeria. Available Www.Budgetoffice.Gov.Ng/2014 Budget Approved.Html (Accessed 5/11/2018).

- Filani, M. O. (1975) Structural Characteristics Of Domestic Air Transport In Nigeria. The Nigerian Geographical Journal, Vol. 18, No 1, Pp. 3- 16.

- Harvey, D. (1951), Airline Passenger Traffic Pattern Within The United States. The Journal Of Air Law And Commerce, Vol. 18, Pp. 157-165.

- Matsumoto, H. (2005), Effects Of New Airports On Hub-Ness Of Cities: A Case Of Osaka, Journal Of The Eastern Asia Society For Transportation Studies, Vol. 6, And Pp. 648 - 663.

- National Bureau Of Statistics (Nbs) (2018), Air Transportation Data, 2018. Available Https// Nigeria.State.Gov.Ng (Accessed On 19/7/ 2019).

- National Population Commission (Npc), (1991), National Population Census Data, 1991.

- National Population Commission (2007), Details Of The Breakdown Of The National And State Provisional Totals, 2006 Census, Pp. B175 -197.

- Nigerian Civil Aviation Authority (Ncaa), (2003), Nigerian Civil Aviation Statistics. Directorate Of Air Transport Regulation, Ncaa, Lagos.

- Nigerian Civil Aviation Authority (Ncaa), (2006), Nigerian Civil Aviation Statistics. Directorate Of Air Transport Regulation, Ncaa, Lagos.

- Nigerian Civil Aviation Authority (Ncaa), (2010), Nigerian Civil Aviation Statistics. Directorate Of Air Transport Regulation, Ncaa, Lagos. 
- Nigerian Civil Aviation Authority (Ncaa), (2014) Nigerian Civil Aviation Statistics. Directorate Of Air Transport Regulation, Ncaa, Lagos.

- Rodrigue, J. P., Comtois C. And Slack, B. (2006), The Geography Of Transport Systems. Routledge, Tailor And Francis Group, London And New York.

- Sivrikaya, O. And Tunç, E. (2013), Demand Forecasting For Domestic Air Transportation In Turkey. The Open Transportation Journal, 2013, Vol. 7, Pages 20-26.

- Taaffe, E. J. (1956), Air Transportation And The United States Urban Distribution. Geographical Review, Vol. Xlvi, No. 2, Pp. 219-238.

- World Population Review (2019) Nigeria Population. Available World Population Review.Com/Countries/Nigeria Population (Accessed 19/7/2019).

\section{AUTHOR'S BIO}

Dr. Emmanuel C. Bardi is a Principal Partner in Emesoch Logistics and Consultancy Services. He obtained his Ph.D. in Transportation Geography from the University of Nigeria, Nsukka, Nigeria. His research focuses on Transportation Geography. Email: nkemchuka@gmail.com 